\title{
About a snail, a toad, and rodents: animal models for adaptation research
}

\section{Eric W. Roubos*, Bruce G. Jenks, Lu Xu, Miyuki Kuribara, Wim J. J. M. Scheenen and Tamás Kozicz}

Department of Cellular Animal Physiology, Faculty of Science, Donders Institute for Brain, Cognition and Behaviour, Centre for Neuroscience, Radboud University Nijmegen, Nijmegen, Netherlands

Edited by:

Billy K. Chow, University of Hong Kong,

China

\section{Reviewed by:}

Maria M. Malagon, University of

Cordoba, Spain

J. C. Cardoso, University of Algarve,

Portugal

\section{*Correspondence.}

Eric W. Roubos, Department of Cellular

Animal Physiology, Faculty of Science

Donders Institute for Brain, Cognition

and Behaviour, Radboud University

Nijmegen, P.O. Box 9010, 6500 GL

Nijmegen, Netherlands.

e-mail:roubos@science.ru.nl
Neural adaptation mechanisms have many similarities throughout the animal kingdom, enabling to study fundamentals of human adaptation in selected animal models with experimental approaches that are impossible to apply in man. This will be illustrated by reviewing research on three of such animal models, viz. (1) the egg-laying behavior of a snail, Lymnaea stagnalis: how one neuron type controls behavior, (2) adaptation to the ambient light condition by a toad, Xenopus laevis: how a neuroendocrine cell integrates complex external and neural inputs, and (3) stress, feeding, and depression in rodents: how a neuronal network co-ordinates different but related complex behaviors. Special attention is being paid to the actions of neurochemical messengers, such as neuropeptide $Y$, urocortin 1 , and brain-derived neurotrophic factor. While awaiting new technological developments to study the living human brain at the cellular and molecular levels, continuing progress in the insight in the functioning of human adaptation mechanisms may be expected from neuroendocrine research using invertebrate and vertebrate animal models.

Keywords: adaptation, $\alpha \mathrm{MSH}$, neurosecretion, non-synaptic communication, synaptic plasticity, urocortin 1

\section{INTRODUCTION}

Adaptation may be considered as the most fundamental and universal process in living organisms to enable survival, reproduction, and evolution in a continuously changing environment. Successful adaptation to either external (e.g., geographical, physical, or social) or internal (e.g., blood oxygen and glucose levels, energy reserve, state of mind) changed conditions, restores internal homeostasis of the organism, thus maintaining physiological and, in "higher" organisms, mental well-being. Reversely, maladaptation disturbs homeostasis and causes severe physiological and, especially in primates, mental disorders (Boeke, 2004; Keller, 2004; Bijlsma and Loeschcke, 2005; Bridle and Vines, 2007; Weinert et al., 2008; Merila, 2009; Ravigne et al., 2009). Whereas adaptation is most advanced in humans, the basal components of adaptation mechanisms are similar throughout the animal kingdom. These components are (1) perception of the environmental change, (2) comparison and integration of this information with other perceived and/or stored information, and (3) release of an either genetically determined, or acquired (by experience, learning, or training) or spontaneous, creative behavioral response that is meant to maintain or restore homeostasis. The similarity between these components between humans and animals provides neuroscientists with the opportunity to study the details of human adaptation mechanisms in selected animal species with experimental approaches that are impossible to apply to humans. For instance, whereas the smallest area that can be studied by functional magnetic resonance imaging in the human brain is not much less than one millimeter in diameter (Yamada et al., 2001), single neurons in the living animal brain, measuring only some tens of a micrometer, can be studied with a large variety of techniques, such as electrical recording from the abdominal R15 neuron of the opisthobranch mollusc
Aplysia californica (e.g., Audesirk and Strumwasser, 1975; Yu et al., 2004), quantitative PCR of mRNAs in a single neuroendocrine melanotrope cell of the amphibian Xenopus laevis (Scheenen et al., 2009) and imaging of neuron migration in the developing mouse olfactory bulb (e.g., Mizrahi et al., 2006). During the past decades these and many other experimental approaches performed with a number of animal species have provided insight into molecular and cellular aspects of adaptation mechanisms in the human nervous and neuroendocrine system, and have started to shed light on the factors that lead to malfunctioning of these systems and consequent disorders like anxiety and depression. Here we will illustrate these approaches and developments by reviewing research on three animal model systems, namely (1) the egg-laying behavior of a snail, Lymnaea stagnalis: how one neuron controls behavior, (2) adaptation to the ambient light condition of a toad, Xenopus laevis: how a neuron integrates complex external and neural inputs, and (3) stress, feeding, and depression in rodents: how a neuronal network co-ordinates different but related complex behaviors. Particular attention has been paid to neuropeptides, which are key players in these models.

\section{THE MULTIPLE PEPTIDE-PRODUCING CAUDODORSAL CELLS OF THE POND SNAIL LYMNAEA STAGNALIS}

In the Department of Zoology at the Free University Amsterdam research on the neuroendocrine system of the basommatophoran snail, Lymnaea stagnalis started in the 1950s when Jan Lever, evolution biologist, endocrinologist, and malacologist, inspired by the discovery of the phenomenon of neurosecretion by Ernst and Berta Scharrer and their colleagues (Scharrer, 1952, 1954; Scharrer and Scharrer, 1953; Sarnat, 1983; Stay, 2000), initiated investigations on neurosecretory cells in freshwater snails. Whereas Lever himself 
found such neurons in the ancylid snail Ferrissia sp. (Lever, 1957), his student Joos Joosse demonstrated such neurons in the pulmonate basommatophoran snail Lymnaea stagnalis (L.), the great pond snail (Lever et al., 1961; Joosse, 1964), and since it turned out that the latter pulmonate mollusc could be easily experimentally handled (e.g., the animal can be narcotized, ganglia, and individual neurons can be recorded, removed and transplanted, and cerebral ganglion homogenates can be injected to induce egg-laying), under Joosse's inspiring guidance, Lymnaea became the animal of choice for physiological research in the Amsterdam laboratory till in the next century (e.g., Boer, 1965; Brink and Boer, 1967; Boer et al., 1968, 1979; Wendelaar Bonga and Boer, 1969; Wendelaar Bonga, 1970, 1971; Sminia, 1972; Roubos, 1973, 1975, 1984; Geraerts and Joosse, 1975; Geraerts and Bohlken, 1976; Kits, 1980; Joosse et al., 1982; Geraerts et al., 1983; Ter Maat et al., 1983a,b, 1988; Vreugdenhil et al., 1985; Joosse, 1986, 1987; De Jong-Brink et al., 1988; Roubos and Van Heumen, 1994; Koene and Ter Maat, 2007).

\section{THE CAUDODORSAL CELLS}

Like other molluscs, L. stagnalis possesses large polyploid neurons (Boer, 1965; Boer et al., 1976), which can be easily identified in vivo in the ganglion ring that forms the central nervous system (Benjamin, 2008). Using the classical neurosecretory stain, paraldehyde fuchsine, and the xanthene stain phloxin B, Joosse observed two neuron clusters at the caudodorsal side of the paired cerebral ganglia, with about 20-40 neuronal cell bodies in the left and about 50-100 in the right, and named them accordingly caudodorsal cells (CDC; Joosse, 1964). Each CDC sends its axon to the periphery of the cerebral commissure where it branches so that a neurohemal area is formed consisting of numerous neurohemal axon terminals (Joosse, 1964; Wendelaar Bonga, 1970). From these terminals, the cells release a wide variety of peptides into the hemolymph of the cephalopedal blood sinus, which surrounds the central nervous system (Wendelaar Bonga, 1970; De Vlieger et al., 1980; Roubos, 1984). These peptides control various aspects of the complex overt and covert egg-laying behavior of this simultaneous hermaphrodite snail.

\section{EGG-LAYING BEHAVIOR}

Lymnaea's internal ("covert") egg-laying behavior comprises the formation of an egg mass containing 100 or more fertilized eggs. Ovulated oocytes are transported from the acini of the ovotestis into the spermoviduct to be self-fertilized. Subsequently, as the eggs pass along the female tract, various accessory sex glands secrete their products (nutrients, protective membranes, glue-like substance) around them, resulting in an egg mass that is eventually deposited onto a proper substrate (Joosse, 1964; Plesch et al., 1971). This internal behavior is accompanied by a behavior that is overt, i.e., visible from the outside, and which is characterized by a sequence of stereotyped phases: resting, when the animal stops locomotion (lasting $\sim 1 \mathrm{~h}$ ), turning with counterclockwise shell movements and high frequency rasping with the buccal eating apparatus to clean the substrate to facilitate egg mass adhesion (also about $\sim 1 \mathrm{~h}$ ), oviposition of the gelatinous egg mass onto the substrate (e.g., a leave or a flat stone) ( $10 \mathrm{~min}$ ) and finally the "inspection phase," when the snail moves along the egg-mass brushing it with lips and tentacles ( $2 \mathrm{~min}$ ) (Ter Maat, 1992). Clearly, the whole process of covert and overt egg-laying behaviors requires accurate co-ordination of the activity of all glandular and muscular activities in order to produce and deposit a well-formed egg mass at the appropriate time and under optimal environmental conditions. This co-ordination is exerted to a large extent by the release of a set of peptides produced by only one neuron type, the CDC.

\section{THE CDC-PEPTIDES}

In nature, egg-laying generally starts early in the morning, shortly after sunrise, when the leaves of water plants increase the oxygen content of the surface water. This triggers in the diurnally rhythmical CDC (Wendelaar Bonga, 1971; Roubos, 1975) a 1 h-lasting discharge of action potentials, which occur synchronously in all CDC of both clusters (Kits, 1980; Ter Maat et al., 1983b), as they are electrically coupled (Roubos et al., 1985). During the discharge the neurohemal axon terminal depolarize, calcium ions enter (Buma and Roubos, 1983), and a set of different peptides is released into the hemolymph after which egg-laying behavior follows. These peptides are derived from a precursor protein, proCDCH-1 (Vreugdenhil et al., 1988), which is encoded by three genes. The genes have been sequenced and the peptides concerned identified by isolation and sequencing, or by fingerprinting by matrix-assisted laser desorption mass spectrometry. The first peptide characterized was the so-called ovulation hormone or caudodorsal cell hormone-1 (CDCH-1; Ebberink et al., 1985). Later, nine other peptides derived from the $\mathrm{CDCH}$-precursor protein were identified, viz. three $\alpha C D C$ peptides ( $\alpha$ CDCP1-11, $\alpha$ CDCP3-11, and $\alpha C D C P 3-10), \beta_{1}-$ and $\beta_{3}$ CDCP, calfluxin, carboxyl-terminally located peptide, $\delta$ CDCP, and عCDCP (Li et al., 1992, 1994; Jiménez et al., 1994).

When injected into the animal, $\mathrm{CDCH}-1$ evokes ovulation and egg-mass formation and triggers the last two phases of overt egg-laying behavior. Of many of the other CDC peptides a function is known, and it has been established that they are responsible for different aspects of the egg-laying behavior. For instance, application in vitro of a specific combination of four CDC peptides, namely CDCH- 1 and the three $\alpha C D C P s$, evokes CDC discharges. This suggests that CDC use auto-excitation to amplify excitatory inputs, thus leading to the generation of the all-or-nothing electrical discharge (Brussaard et al., 1990). Another CDC peptide, calfluxin, stimulates the influx of extracellular calcium ions into the secretory cells of a female accessory sex gland, the albumen gland, which produces a galactogenrich fluid that surrounds the eggs and serves as nutrient for the developing embryo (Dictus et al., 1987). More recently, two novel peptides, not encoded by the $\mathrm{CDCH}-1$ precursor, were detected in the CDC by mass spectrometry. They exhibit temporal quantitative changes similar to those of CDC peptides, suggesting that they are also involved in Lymnaea's egg-laying behavior (Jiménez et al., 2004, 2006).

Interestingly, using polyclonal antisera directed against $\mathrm{CDCH}-1, \alpha \mathrm{CDCP}$ and $\beta \mathrm{CDCP}$ resulted in positive immunoreaction in the insects Sarcophaga bullata (Diptera), Leptinotarsa decemlineata (Coleoptera), Locusta migratoria, and Periplaneta americana (Orthoptera) (Theunis et al., 1990). This indicates that the functional significance of these peptides exceeds that of the class of mollusca. 
At the ultrastructural level, in addition to "elementary" secretory granules (Wendelaar Bonga, 1970, 1971), the CDC contain larger, strongly electron-dense granules, which are formed by the Golgi apparatus and thought to be involved in intracellular degradation of secretory material (Roubos, 1976). They are $\sim 3$ times more immunopositive for calfluxin than the secretory granules, while their immunoreactivity with anti- $\alpha$ CDCP is even 10 times higher than that of the secretory granules, suggesting that calfluxin and $\alpha C D C P$ are processed and sorted in (quantitatively) different ways (Van Heumen and Roubos, 1991; Van Heumen et al., 1992). Indeed, pro-CDCH-1 is initially split within the Golgi apparatus into carboxyl- and amino-terminal parts, each of which are sorted to distinct vesicle classes with different destinations, so that in the cerebral commissure peptides derived from the carboxyterminal part are present at a many-fold higher concentration than those derived from the aminoterminal part (Jiménez et al., 1994; Li et al., 1994). Interestingly, in the cerebral commissure, calfluxin-immunoreactivity is not only present in the neurohemal CDC terminals in the periphery but also in collaterals from the CDC axons, running in the inner, non-neurohemal part of the commissure (Schmidt and Roubos, 1987, 1988, 1989). With the ultrastructural tannic acid method (Roubos and Van der Wal-Divendal, 1980; Roubos and Buma, 1982) exocytosis of CDC peptides was demonstrated from thin, blindly ending branches of this collateral system in a non-synaptic fashion into the intercellular space inside the commissure (Roubos and Buma, 1982; Buma et al., 1984; Buma and Roubos, 1986). The released peptides probably act on receptors of remotely located neuronal elements (Van Heumen et al., 1992). A likely target for such non-synaptic control by CDC peptides in the commissure is a long process of the so-called Ring neuron, which has its cell body in the right cerebral ganglion. When the CDC fire a discharge, this interneuron becomes active. It has synaptic connections with pedal ganglion neurons involved in the control of locomotion and shell movement, and it might cause an inhibition of locomotion and the adoption of the posture typical of the resting phase (Jansen and Ter Maat, 1985; Jansen et al., 1985). Of these pedal neurons, the right pedal $\mathrm{N}$ motor neurons (RPeN) are inhibited during the resting phase of egg laying but are active at the onset of the turning phase. They are activated by application of $\beta_{3}$ CDCP but not by $\alpha$ CDCP or calfluxin (Hermann et al., 1997), whereas the ovulation hormone inhibits RPeN motor neurons so that no turning behavior occurs during oviposition. The effects of injection of these CDC peptides into intact animals correlate well with the effects of these peptides on RPeN neurons. Injection of $\beta_{3}$ CDC peptide and $\alpha C D C P$ also increases the rate of rasping movements and increases shell turning, which is consistent with the normal increases in rasping seen during the turning phase of natural egg-laying behavior (Hermann et al., 1997).

\section{THE INTEGRATIVE ACTION OF THE CDC}

So, whereas the precise relationships between the various CDC peptide secretory products and all locations and functions of the CDC targets in Lymnaea are not completely known, it is clear that the CDC control essential aspects of the covert and overt egg-laying behavior of this snail by the release of (sets of) peptides derived from one precursor, from two sites in the cerebral commissure, either into the blood (from neurohemal axon terminals) or in a non-synaptic way (from the collateral system inside the commissure) to other neurons. In this way some peptides control the covert behavior acting as neurohormones, whereas others regulate aspects of the overt behavior via non-synaptic secretion of neurotransmitters inside the nervous system (Figure 1).

This example of multiple peptidergic control of egg-laying behavior in a snail illustrates the evolutionary significance of large hormone precursor molecules for the integrative regulation of essential behaviors that serve the survival of a species. CDC are common in basommatophoran snails (Roubos and Van de Ven, 1987) and their actions are beautifully matched by the control of egg-laying in the opisthobranch slug Aplysia californica by the neuroendocrine bag cells, which in many respects resemble the CDC of Lymnaea and represent one of the iconic animal research models in biology (Pinsker and Dudek, 1977; Kandel et al., 1980; Rothman et al., 1983; Scheller et al., 1983; Sigvardt et al., 1986). In this respect, it is essential to know how these egg-laying neurons are able to react upon changes in the environment that are relevant for the survival of the offspring. In the case of Lymnaea, this aspect has been studied only to a limited degree. Whereas the CDC are under strong neuronal control (Roubos, 1976) and various stimuli are known to either activate (e.g., temperature, feeding, copulation, clean water) or inactivate (e.g., dirty water, tactile stimulation) the CDC and, hence, modulate egg-laying behavior such that the egg mass will be deposited only when the environmental conditions are optimal

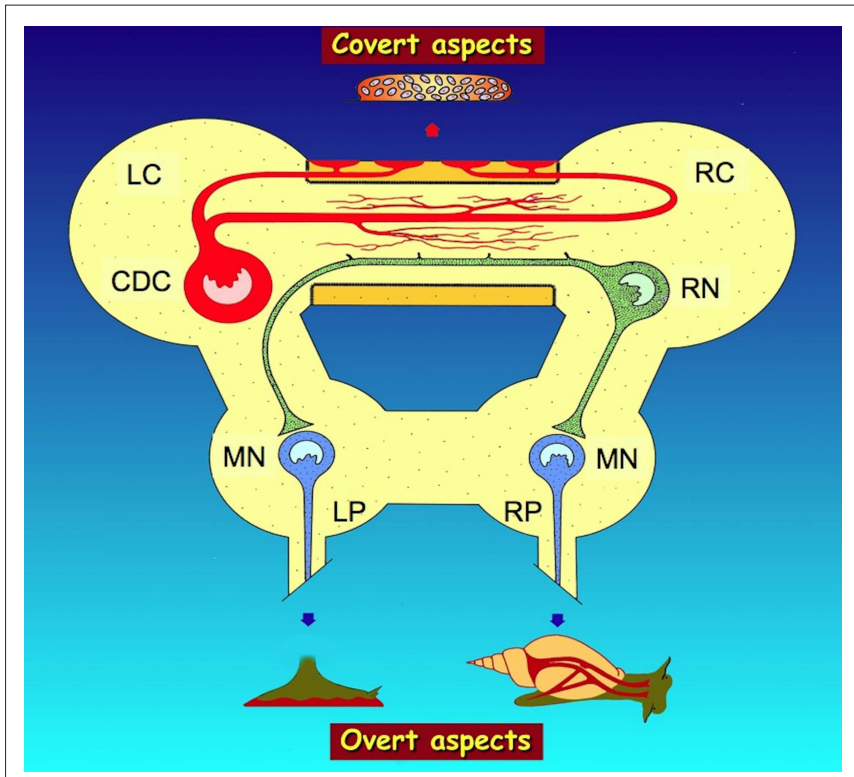

FIGURE 1 | Summarizing scheme of the regulation by the caudodorsal cells (CDC) of Lymnaea stagnalis of overt (visible) and covert (invisible) aspects of egg-laying behavior by, respectively, neurohemal peptide release from axon terminals in the periphery of the cerebral commissure and non-synaptic peptide release from axon collaterals in the inner part of the commissure. Overt aspects include the activation of muscles in the foot for locomotion during substrate cleaning (bottom left) and of muscles attached to the shell for shell turning (bottom right), while covert aspects include the induction of ovulation and the activation of accessory sex glands to produce an egg mass (top). For details on these aspects, see text. LC, left cerebral ganglion; LP, left pedal ganglion; $M N$, motor neurons; $R C$, right cerebral ganglion; RN, Ring neuron; RP, right pedal ganglion. 
(Ter Maat et al., 1983a; Dogterom et al., 1984a,b; Hermann et al., 1997), the neuronal systems that mediate environmental information toward the CDC have been only fragmentary elucidated. To illustrate the way one cell type, in our case a neuroendocrine cell, is regulated by a wide variety of environmental inputs that act via various brain centers and converge via a host of neurotransmitters and neurohormones on the cell, below we will pay attention to the second animal model, the toad Xenopus laevis and the multiple control of the neuroendocrine melanotrope cells in its pituitary pars intermedia.

\section{THE MELANOTROPE NEUROENDOCRINE TRANSDUCER CELLS OF THE SOUTH AFRICAN TOAD XENOPUS LAEVIS}

Since the discovery that vertebrates of all classes have a rich store of a hormone that controls pigment migration of the skin in response to changed ambient light condition (Hogben, 1924; Houssay and Ungar, 1924; Hogben and Slome, 1931), neuroendocrine control of background adaptation has become a favorite model to study how a natural environmental change can evoke an adaptive response (Hopkins, 1970; Thornton et al., 1970; Weatherhead and Whur, 1972; Vaudry et al., 1976, 1983, 1984; Volcanes and Weatherhead, 1976; Jenks, 1977; Jenks et al., 1979; Loh and Jenks, 1981; Martens et al., 1981a). In the Utrecht Department of Zoology, research on the endocrine control of background adaptation in the South African clawed toad Xenopus laevis was initially focused on pigment migration in skin melanophores (Burgers, 1956; Burgers and Van Oordt, 1962; Van de Veerdonk, 1969) but soon extended to the control of $\alpha$-melanophore-stimulating hormone ( $\alpha \mathrm{MSH})$ production by melanotrope cells in the pars intermedia of the pituitary gland (Burgers et al., 1963; Goos, 1969; Van Oordt et al., 1972; Terlou and Van Straaten, 1973; Terlou et al., 1975). In 1975 Bram Van Overbeeke and Bruce Jenks transferred the latter research line to our Nijmegen Zoology Department. Conducted in close collaboration with research groups working on amphibian melanotropes in e.g., France (Vaudry et al., 1983, 1984, 2005; Van Strien et al., 1996; Bidaud et al., 2004; Galas et al., 2009), Italy (Tuinhof et al., 1994), Spain (Vazquez-Martinez et al., 1999), Sweden (Blomqvist et al., 1995), Japan (Kikuyama et al., 1993; Berghs et al., 1998; Tonosaki et al., 2004) and the USA (Calle et al., 2005; Roubos et al., 2009; Eagleson et al., 2010), the Nijmegen research eventually provided a rather comprehensive picture of the various elements in Xenopus laevis that constitute the complex system responsible for the transduction of environmental information into $\alpha \mathrm{MSH}$ output. This system involves sensory organs, brain centers with diverse neurochemical messengers, and melanotrope cell receptors and related intracellular signaling pathways that control and co-ordinate the expression of the pro-opiomelanocortin (POMC) gene, POMC biosynthesis and processing, and posttranslational modification and secretion of $\alpha \mathrm{MSH}$ and associated POMCderived peptides (Roubos et al., 2005, 2010; Jenks et al., 2007; Scheenen et al., 2009).

\section{POMC PEPTIDES}

The production of Xenopus $\alpha \mathrm{MSH}$ starts with the biosynthesis of POMC (Martens et al., 1982; Martens, 1986; Ayoubi et al., 1992; Deen et al., 1992), which is cleaved by prohormone convertase PC2 (Dotman et al., 1998). A phenomenon unique to amphibians is the posttranslational acetylation reaction to form mature $\mathrm{N}$-acetylated $\alpha \mathrm{MSH}$, which increases the bioactivity of the peptide $\sim 10$-fold and is associated with the exocytotic release of the peptide (Martens et al., 1981b; Van Strien et al., 1995b). In Xenopus, the final processing product of the C-terminal region of POMC is $N$-acetyl- $\beta$-endorphin(1-8; Van Strien et al., 1993). In addition, POMC cleavage gives rise to $\gamma \mathrm{MSH}$ and $\mathrm{N}$-terminal fragments of the precursor protein (Van Strien et al., 1995a), but the biological significance of these peptides is not known.

The Xenopus pars intermedia contains about 60,000 melanotrope cells, which are activated when the animal is placed on a black (dark) background and inactivated when the background is white (light) (Roubos et al., 1993, 2002, 2005; Roubos, 1997; Jenks et al., 2003, 2007). The activation of the "black melanotrope" is reflected at the ultrastructural level by a well-developed biosynthetic secretory machinery (rough endoplasmic reticulum and Golgi apparatus) and the presence of newly formed, electron-dense secretory granules (De Rijk et al., 1990b). In contrast, "white", inactive cells lack these cell organelles almost completely and mainly store old, rather electron-lucent, secretory granules. Melanotrope secretory granules contain all peptide end products of POMC (Berghs et al., 1997) but also the protein, BDNF (Kramer et al., 2002a).

In addition to background illumination, stress, and low temperature change melanotrope secretory activity (Ubink et al., 1997; Tonosaki et al., 2004). The external stimuli reach the melanotrope cells via a number of brain centers that either inhibit or stimulate the biosynthesis of POMC, the processing of POMC and/or the secretion of $\alpha \mathrm{MSH}$ and associated POMC-derived peptides. The hypothalamic suprachiasmatic nucleus (SCN) produces NPY, dopamine (DA), and $\gamma$-aminobutyric acid (GABA), neurotransmitters that all inhibit the melanotropes, in a synaptic way. Two extrahypothalamic brain centers that stimulate melanotrope cell activity are the locus ceruleus (LC) and the raphe nucleus (RN). But the most important stimulatory control center of the melanotrope cells is the hypothalamic magnocellular nucleus (MCN), which produces up to eight neurochemical messengers that stimulate melanotrope cell activity in vitro, and likely reach the melanotrope cells by simple diffusion or via blood flow from the neural to the intermediate lobe, after being released from neurohemal axon terminals in the pituitary pars nervosa (Tuinhof et al., 1993a, 1994; Ubink et al., 1998, 1999; Van Wijk et al., 2010). More details on the regulatory centers and their messengers are given below.

\section{THE SCN}

A positive hybridization signal with a Xenopus-specific probe for NPY mRNA was found in neurons in the ventrolateral SCN (Tuinhof et al., 1993b). With in situ hybridization as well as with immunocytochemistry, the SCN neurons proved to be NPY-positive only in animals adapted to a white background; Xenopus adapted to a black background showed no staining. Quantitative image analysis revealed that this effect of white background adaptation is specific for SCN neurons because no effect could be demonstrated for NPY contents of neurons in the ventral infundibular nucleus and the ventromedial thalamic nucleus. These results indicate that neurons in the SCN enable the adaptation of X. laevis to a white background by producing and releasing NPY that inhibits the 
secretion of $\alpha \mathrm{MSH}$ from the melanotropes. These neurons have been named "suprachiasmatic melanotrope-inhibiting neurons" or SMINs (Tuinhof et al., 1993b, 1994).

In vitro superfusion studies show that $\alpha \mathrm{MSH}$ release is inhibited not only by NPY but also by GABA and DA (Verburg-Van Kemenade et al., 1986a,c). These three neurotransmitters coexist in synaptic contacts on the melanotropes (De Rijk et al., 1990a, 1992; Van Strien et al., 1991) that, when the animal is on a dark background, decrease in size whereas the melanotropes become larger and more active. Reversely, on a light background, the synapses grow while melanotropes become small and inactive (Berghs and Roubos, 1996). NPY and dopamine co-exist in electron-dense vesicles and GABA is stored in electron-lucent ones (De Rijk et al., 1992), suggesting that these neurotransmitters are differentially released. GABA inhibits secretion through both $\mathrm{GABA}_{\mathrm{a}}$ and $\mathrm{GABA}_{\mathrm{b}}$ receptors (Verburg-Van Kemenade et al., 1987b; Buzzi et al., 1997) while DA inhibits secretion through $\mathrm{D}_{2}$ receptors (Verburg-Van Kemenade et al., 1986d; Martens et al., 1993), both inhibitions being short-lasting. NPY inhibits $\alpha$ MSH secretion through Y1 receptors (Verburg-Van Kemenade et al., 1987a; Scheenen et al., 1995; Zhang et al., 2006), which is a long-lasting process (Leenders et al., 1993). Double and triple neurotransmitter immuno-electron microscopy combined with retrograde tracing with the fluorescent DiI tracers (Tuinhof et al., 1994; Ubink et al., 1998) demonstrated that these three transmitters are produced by the SMINs. At the ultrastructural level, the SMINs show a high degree of plasticity, containing more electron-dense vesicles and a larger extent of rough endoplasmic reticulum in white- than in black-adapted animals. Immunocytochemistry in combination with confocal laser scanning microscopy revealed co-existence of NPY and synaptobrevin in spots in the direct vicinity of the SMINs, suggesting the existence of NPY-containing synapses on these cells. In black-adapted animals, symmetric Gray type II synapses were observed on the soma of the SMINs, indicating an inhibitory input to these cells. The synaptic profiles contained electron-lucent and electron-dense vesicles, suggesting the involvement of both a classical neurotransmitter and a neuropeptide (possibly NPY) in this input. In whiteadapted animals, synapses were only found at some distance from the SMIN somata. These findings indicate a striking plasticity of the innervation of the SMINs in relation to background adaptation and support the hypothesis that the SMINs are innervated by NPY-containing interneurons that inhibit SMIN activity in blackadapted animals (Kramer et al., 2002b). At the same time, in addition to the SMINs in the ventral SCN, a dorsomedial and a caudal group of SCN neurons were distinguished that differed from the SMINs and from each other as to number, size, and shape (Kramer et al., 2001a,b). These neurons also showed different degrees of NPY-immunoreactivity in response to changed background light condition. Melanotrope cells of black-adapted animals have a much higher expression of the "exocytosis proteins" SNAP25, Xunc-13, and DOC2 (Kolk et al., 2000, 2001; Kramer et al., 2001a) than whiteadapted ones, establishing that the degree of expression of such proteins is a good parameter to measure secretory activity (Berghs et al., 1999). It was then found that while the ventrolateral SMINs express most DOC2 mRNA in white-adapted animals, NPY neurons in the dorsomedial group had highest secretory activity under the black-adaptation condition (Kramer et al., 2001b). Therefore, the latter neurons may inhibit the SMINs in black-adapted animals. NPY-positive neurons in the caudal group have similar secretory dynamics as the dorsomedial NPY neurons, indicating that they also play a role in background adaptation, distinct from that exerted by the ventrolateral and dorsomedial group (Kramer et al., 2001b).

The pathway by which information about the ambient light condition reaches the melanotropes has been elucidated. After filling the optic nerve with horseradish peroxidase, labeled axons were traced in anterograde direction up to the suprachiasmatic area where they make synaptic contact with SCN neurons that positively reacted to both anti-NPY and anti-tyrosine hydroxylase sera. Apparently, a retinosuprachiasmatic pathway is involved in the control of the melanotrope cells during the process of background adaptation (Tuinhof et al., 1994), establishing a complete pathway from sensory organ via brain centers and pituitary gland to target (skin melanophores).

\section{THE LC AND RN}

In vitro superfusion studies show that serotonin has a dose-dependent stimulatory effect on $\alpha \mathrm{MSH}$ release from melanotrope cells (Verburg-Van Kemenade et al., 1986b). Retrograde neuronal tract tracing with Fast DiI applied to the pituitary pars intermedia identified labeled neurons in, not only, the SCN but also the LC and RN (Ubink et al., 1999). Whereas the LC produces noradrenalin, which probably stimulates melanotrope cell activity (VerburgVan Kemenade et al., 1986b; Roubos et al., 2002), it seems likely that the melanotrope cells in the Xenopus pars intermedia are also innervated by a serotonergic network originating from neurons in the RN; this network represented the first anatomically identified stimulatory input to the pars intermedia of this species (Ubink et al., 1999).

\section{THE MCN}

The MCN in the preoptic part of the Xenopus hypothalamus, is the main hypothalamic stimulatory center of Xenopus melanotrope cells (Tuinhof et al., 1994). Immunocytochemistry has revealed a large "bouquet" of neurochemical messengers in Xenopus MCN perikarya and in neurohemal axon terminals in both the median eminence and the pituitary pars nervosa (Van Wijk and Roubos, 2009; Van Wijk et al., 2010). In addition to mesotocin, vasotocin, and corticotropin-releasing factor (CRF), these messengers include thyrotropin-releasing hormone (TRH; Verburg-Van Kemenade et al., 1987c; Tonosaki et al., 2004), BDNF (Wang et al., 2004, 2005; Calle et al., 2006c), metenkephalin (Van Wijk et al., 2010), Ucn1 (Calle et al., 2005), pituitary adenylyl cyclase-activating polypeptide (PACAP; Kidane et al., 2007a, 2008) and cocaine- and amphetamine-regulated transcript peptide (CART; Roubos et al., 2008). Except for CART, all these factors can stimulate the secretion of $\alpha \mathrm{MSH}$ from melanotrope cells in vitro. Possibly, various environmental factors (background light condition, temperature, feeding condition, stress) modulate melanotrope cell activity in a differential way, acting via specific subpopulations of MCN neurons and different (sets of) neurochemical messenger. Indeed, the neuronal population of the MCN appears to be very heterogeneous, as immuno-electron microscopy of their neurohemal area in the pars nervosa demonstrated the presence of six types of axon terminal based on the size, shape, and electron-density of their 
respective secretory granules. These terminal types are neurochemically distinct because each type has its own set of neurochemical messenger (Van Wijk et al., 2010). Experimental evidence for differential control of MCN neurons comes from studies in which Xenopus was fasted for 3 weeks, leading to decreased amounts of CART, metenkephalin, and Ucn 1 and to an increase in the amount of CRF (Calle et al., 2006b). These effects were especially obvious in the ventral part of the MCN and less pronounced in the medial and dorsal parts of the nucleus, suggesting a specialization of neuronal subpopulations within the MCN. The data support the hypothesis that in X. laevis, the MCN plays a pivotal role in feeding-related processes The relation between this function of the MCN with that of controlling background adaptation via the melanotrope cells is elusive.

\section{INTEGRATED RESPONSE OF THE SCN, MCN, AND MELANOTROPE CELLS TO LOW TEMPERATURE}

Low temperature has a remarkable effect on the skin adaptation process in Xenopus laevis, as a temperature below $8^{\circ} \mathrm{C}$ stimulates $\alpha \mathrm{MSH}$ secretion and skin darkening, with a maximum stimulation at $5^{\circ} \mathrm{C}$, independent of the illumination state of the background (Tonosaki et al., 2004). No skin darkening occurs in toads from which the neurointermediate lobe has been extirpated, indicating that low temperature stimulates $\alpha \mathrm{MSH}$ release from melanotrope cells. Separate in vitro experiments show that low temperature does not act directly on these cells to alter secretory activity. Lowering the ambient temperature of animals from 22 to $5^{\circ} \mathrm{C}$, decreased expression of the immediate early gene cFos in the NPY-producing SMINs in the SCN and increases this expression in TRH-containing neurons in the MCN. Apparently, temperatures around $5^{\circ} \mathrm{C}$ inactivate the SMINs in the SCN and activate TRH-neurons in the $\mathrm{MCN}$, resulting in enhanced $\alpha \mathrm{MSH}$ secretion from the melanotropes, darkening the skin of white-adapted X. laevis (Tonosaki et al., 2004).

\section{STEROIDS}

Xenopus melanotrope cells are not only under control of classical neurotransmitters and neuropeptides. Immunocytochemical morphometry with antisera raised against Xenopus glucocorticoid and mineralocorticoid receptors, revealed downregulation of the former and upregulation of the latter receptor during dark background adaptation. Corticosterone did not affect short-term processes like the generation of intracellular calcium dynamics and $\alpha \mathrm{MSH}$ secretion, suggesting a role for these receptors in long-term processes in the melanotropes (Roubos et al., 2009). The origin of the steroid factors concerned and the physiological significance of their regulation of the melanotrope cells are not known.

\section{INTRACELLULAR SIGNALING}

Many of the first messengers controlling Xenopus melanotrope cell activity act via $G$ protein-coupled receptor mechanisms regulating adenylyl cyclase (AC) in its production of cAMP. For instance, $D_{2}$, $\mathrm{Y}_{1}$, and $\mathrm{GABA}_{\mathrm{b}}$ receptors inhibit $\mathrm{AC}$, whereas the CRFR1 receptor (Calle et al., 2006a) and the $\beta$-adrenergic receptor stimulate the enzyme. The intracellular mechanisms regulating the secretory process in Xenopus melanotropes have been extensively reviewed (Scheenen et al., 1996; Jenks et al., 1998, 2003; Bidaud et al., 2004;
Galas et al., 2005), but some special attention should be given here to recent studies on calcium signaling in the melanotrope. The cAMP-dependent kinase protein kinase A acts on components of a membrane potential oscillator machinery to stimulate so-called $\mathrm{Ca}^{2+}$ oscillations, whereas activation of the GABA receptor gives rise to membrane depolarization that acts on this machinery to give a transitory stimulation followed by an inhibition (Buzzi et al., 1997; Corstens et al., 2006). Moreover, the $\beta / \gamma$ subunit of the $G$ protein that is activated by $\mathrm{D}_{2}, \mathrm{Y}_{1}$, and $\mathrm{GABA}_{\mathrm{b}}$ receptors acts directly on $\mathrm{N}$-type and R-type but not on L-type and P/Q-type voltageoperated calcium channels (Zhang et al., 2004, 2006). Below we will deal with the role of $\mathrm{Ca}^{2+}$ channel types and properties of $\mathrm{Ca}^{2+}$ oscillations in the regulation of melanotrope cell activity.

Calcium channels play a crucial role in determining the secretory activity of Xenopus melanotropes (Zhang et al., 2005). Melanotropes from black background-adapted toads have a 2 times larger diameter, a 2.5-fold larger membrane capacitance, a 2-fold higher high-voltage-activated (HVA) current density, a 10\% smaller $\mathrm{Ca}^{2+}$-dependent inactivation, and L-type channels with 5 times slower activation and inactivation kinetics. Furthermore, whiteadapted melanotropes possess low-voltage-activated (LVA) type $\mathrm{Ca}^{2+}$ channels, which are lacking in cells from black-adapted animals. These results indicate that HVA L-type channel kinetics differ in relation to environmentally induced changes in cellular secretory state, probably mediated via intracellular $\mathrm{Ca}^{2+}$-buffering, whereas the occurrence of $\mathrm{LVA} \mathrm{Ca}^{2+}$ channels may depend on environmentally controlled channel gene expression (Zhang et al., 2008).

Periodic fluctuations in the intracellular $\mathrm{Ca}^{2+}$ concentration play an important role in melanotrope signaling (Scheenen et al., 1993). Such $\mathrm{Ca}^{2+}$ oscillations are generated at the plasma membrane through opening of N-type and R-type $\mathrm{Ca}^{2+}$ channels (Lieste et al., 1998a; Zhang et al., 2005) and may drive the secretion of $\alpha$ MSH. By mobilizing intracellular calcium stores ("calcium-induced calcium release"; Koopman et al., 1999) the $\mathrm{Ca}^{2+}$ influx also initiates a self-propagating $\mathrm{Ca}^{2+}$ wave that enters the nucleus (Scheenen et al., 1996; Koopman et al., 2001) and possibly induces gene expression (Scheenen et al., 1994, 1996; Lieste et al., 1998b; Jenks et al., 2003; Van den Hurk et al., 2005b; Kuribara et al., 2010a). The combined kinetics of all subcellular $\mathrm{Ca}^{2+}$ signals determines the shape of the total cellular $\mathrm{Ca}^{2+}$ signal, but these contributions to the signal vary in time. Near the plasma membrane, the intracellular $\mathrm{Ca}^{2+}$ concentration rises and declines more rapidly than in more central parts of the cytoplasm (Koopman et al., 2001). Possibly, the differences in spatial kinetics of the $\mathrm{Ca}^{2+}$ signal reflect a mechanism by which the same cellular $\mathrm{Ca}^{2+}$ signal carries different regulatory information to different subcellular regions of the cell, thus evoking differential cellular responses, e.g., as to gene expression compared to hormone secretion.

\section{AUTOCRINE MECHANISMS}

Several stimulatory autocrine mechanisms act in the Xenopus melanotrope. One of these is the $\mathrm{Ca}^{2+}$ sensing receptor, a $\mathrm{G}$ protein-coupled receptor with extracellular $\mathrm{Ca}^{2+}$ as the natural ligand. Possibly, this receptor is activated by $\mathrm{Ca}^{2+}$ released from exocytozing secretory granules (Van den Hurk et al., 2003, 2005a, 2008). In addition, the Xenopus melanotrope releases acetylcholine that stimulates $\alpha \mathrm{MSH}$ secretion through a muscarinic $\mathrm{M}_{1}$ receptor mechanism (Van Strien et al., 1998). 
A special aspect of autocrine melanotrope cell regulation is the action of BDNF. BDNF's production by melanotropes strongly suggests a role as autotransmitter (Kramer et al., 2002a; Kidane et al., 2007b). In fact, adding BDNF in vitro to melanotropes stimulates the biosynthesis of POMC (Kramer et al., 2002a) whereas its coexistence with $\alpha \mathrm{MSH}$ in melanotrope secretory granules (Wang et al., 2004) indicates that release of the neurotrophin is enhanced when animals are on a black background, thus helping to maintain the high rate of POMC biosynthesis required by such animals. Indeed, Xenopus melanotropes express receptors for BDNF (Kidane et al., 2007b), namely the TrkB receptor, the truncated $\operatorname{TrkB}$ receptor and the 75 neurotrophin receptor, $\mathrm{p} 75^{\mathrm{NTR}}$. Of these, the expressions of truncated TrkB and $\mathrm{p} 75^{\mathrm{NTR}}$ are upregulated in black melanotropes, possibly enhancing the sensitivity of the melanotrope cell to BDNF. The melanotrope cells of animals adapting to a black background undergo a dramatic increase in size (De Rijk et al., 1990b) but when melanotropes are treated with anti-BDNF serum, no such cell growth occurs, indicating that this plastic melanotrope cell growth under stimulated conditions depends on autocrine action of BDNF, probably via a TrkB-dependent ERK-mediated signaling pathway (Kuribara et al., 2010b).

The Xenopus BDNF gene contains six promoter-specific $5^{\prime}$-exons and a single $3^{\prime}$ protein-encoding exon (Kidane et al., 2009), which are organ-specifically expressed. In particular, the expression of BDNF transcript IV is increased by $\sim 150$ times in the melanotropes by transferring animals from a white to a black background. As mentioned earlier, cAMP and $\mathrm{Ca}^{2+}$ are major second messengers in the Xenopus melanotrope. One of the processes they likely drive is the expression of BDNF transcript IV, because the promoter region for this transcript possesses a cAMP-responsive element and two $\mathrm{Ca}^{2+}$-responsive elements. POMC itself contains no cAMP or $\mathrm{Ca}^{2+}$-responsive elements and it therefore seems possible that (autocrine) BDNF would activate other intracellular signaling cascades (e.g., extracellular regulated kinase) to act on POMC gene expression (Kidane et al., 2009). Supporting this idea is the observation that upon transferring Xenopus to a black background, melanotrope $B D N F$ transcript IV is much faster upregulated (17 times higher within $6 \mathrm{~h}$ of transfer) than $P O M C$ transcript (no increase at $6 \mathrm{~h}$, only a 3 -fold increase after 24 h; Kidane et al., 2009). Another (indirect) pathway involved in the regulation of $P O M C$ expression, is likely via cFos. Xenopus POMChas an activator protein 1 (AP-1) site that can be a potential target for cFos (Deen et al., 1992), and cFos expression increases rapidly (within $1 \mathrm{~h}$ ) upon placing animals on a black background (Kidane et al., 2009).

\section{IN CONCLUSION}

The neuroendocrine melanotrope cell of the amphibian Xenopus laevis reveals how multiple external stimuli can converge on a single neuroendocrine cell type to change its activity in such a way that the resulting secretory response evokes the optimal physiological reaction needed by the animal to adapt to a changed environmental condition (Figure 2).

Taken together with the example of the CDC of the snail Lymnaea, this picture of the Xenopus melanotrope cell shows how a neural cell can transduce complex environmental information into an adaptive response. In the last part of this review, we will demonstrate how this integrative capacity of a neuron contributes to the integrated actions of different brain centers that are involved in the adaptation to stress under conditions of changed energy storage: the role of the Ucn1-producing neurons in the vertebrate midbrain Edinger-Westphal (EW) nucleus.

\section{THE UCN1-NEURONS OF THE RODENT NON-PREGANGLIONIC EDINGER-WESTPHAL NUCLEUS}

In Nijmegen, research on the role of the EW nucleus in stress adaptation and related adaptive behaviors started in 2002, when Tamás Kozicz joined the Department of Cellular Animal Physiology. The EW nucleus is traditionally known to contain cholinergic preganglionic parasympathetic neurons that are involved in oculomotor adaptation (Edinger, 1885; Westphal, 1887; Burde et al., 1982). However, upon the discovery of Ucn1 (Vaughan et al., 1995) and the notion that the majority of $U \mathrm{cn} 1$ in the mammalian brain is present in non-cholinergic EW neurons that do not innervate the ciliary ganglion, the part of the EW that contains these Ucn1-neurons has been named non-preganglionic Edinger-Westphal nucleus (npEW; Cavani et al., 2003; Ryabinin et al., 2005; Weitemier et al., 2005; Gaszner et al., 2007; Kozicz, 2007b) (whereas some authors have proposed to rename these neurons "perioculomotor subgriseal neuronal stream”; see May et al., 2008).

\section{CONNECTIONS OF THE NPEW}

Although all afferent and efferent brain areas of the npEW have not been identified in each mammalian species studied, a situation largely due to the difficulty to reliably inject axonal tracers into this tiny midbrain nucleus, it is clear that the npEW possesses multiple inputs like shown for the Xenopus melanotrope cell and multiple outputs as described for the CDC of Lymnaea. The npEW receives projections from the dorsal raphe in hamster (Morin and Meyer-Bernstein, 1999), from the parabrachial nucleus in rat (Saper and Loewy, 1980) and from the ventral tegmental area in mice (Bachtell et al., 2002). However, whether these projections target npEW-Ucn1 neurons is unknown. Nevertheless, npEW Ucn1-perikarya are surrounded by many types of axon terminal, containing various neurotransmitters/neuropeptides and their synthesizing enzymes, such as orexin (Baldo et al., 2003; T. Kozicz, personal communication), serotonin (Takeuchi et al., 1982; Clements et al., 1985), dopamine- $\beta$-hydroxylase (Baldo et al., 2003), and NPY (Yamazoe et al., 1985). NPY axon terminals are juxtaposed to Ucn1-neurons in both the rat and human npEW, and the action of NPY within the npEW is mediated via both Y1 and Y5 receptors (Gaszner et al., 2007). As to output of the npEW, up to now the lateral septal nucleus and the spinal cord have been implied to be specific targets of npEW-Ucn1 projections (Bittencourt et al., 1999). However, most likely npEW-Ucn1 neurons have many more targets in view of the wealth of neurotransmitters they produce: besides Ucn 1, they contain CART (Couceyro et al., 1997), which co-exists with Ucn1 in secretory granules (Van Wijk et al., 2009), cholecystokinin (Maciewicz et al., 1984; Innis and Aghajanian, 1986; Lanaud et al., 1989), neuropeptide B (Tanaka et al., 2003; Dun et al., 2005), Substance P (Maciewicz et al., 1983; Phipps et al., 1983; Otake, 2005) and nesfatin (Xu et al., 2009, 2010; Okere et al., 2010). 


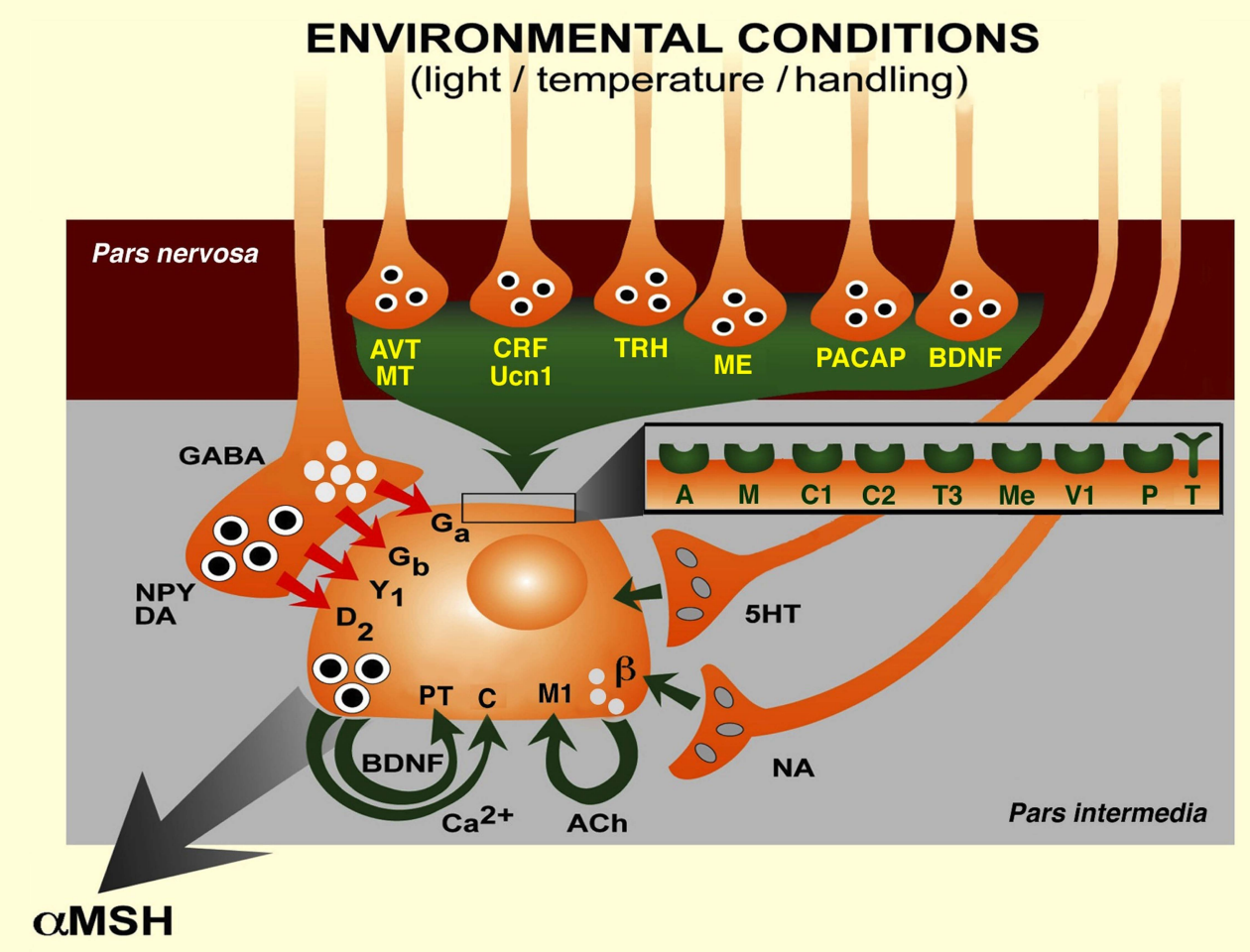

FIGURE 2 |Transduction of various physiological environmental stimuli to the melanotrope cell of Xenopus laevis controlling the secretion of $\alpha \mathrm{MSH}$, via neurohemal nerve terminals in the pars nervosa and from synaptic terminals in the pars intermedia of the pituitary gland. $5 \mathrm{HT}$,

5-hydroxytryptamine (serotonin); A, arginine-vasopressin receptor; ACh, acetylcholine; $A V T$, arginine-vasopressin; $\beta$, $\beta$-adrenergic receptor; $B D N F$, brain-derived neurotrophic factor; $\mathrm{C}$, calcium-sensing receptor; $\mathrm{C}$, corticotropinreleasing factor receptor $1 ; \mathrm{C} 2$, corticotropin-releasing factor receptor $2 ; \mathrm{Ca}^{2+}$

Another approach to find targets of the npEW would be to assess the sites of cognate receptors for Ucn1. Ucn 1 is most strongly bound by two CRF receptor types that bind not only CRF but also the other members of the CRF-peptide family, urotensin-I and sauvagine, urocortin 2 and urocortin 3 (Kozicz, 2009). The ubiquitous presence of both CRFR1 and CRFR2 in the mammalian central nervous system (Korosi et al., 2006, 2007; Kozicz, 2007a) indicates that npEW-Ucn 1 neurons have potentially widespread effects (Hsu and Hsueh, 2001; Lewis et al., 2001; Reyes et al., 2001; Hauger et al., 2006; Kozicz, 2007b; Pan and Kastin, 2008).

The hypothalamo-pituitary adrenal (HPA)-axis reveals diurnal activity (Watabe et al., 1987). In view of the assumed relation between the axis and the npEW, the presence of such rhythmicity and its possible underlying molecular mechanism (clock genes) were investigated in the Ucn1-neurons of the npEW. They reveal co-existence of diurnal rhythms in Period 2 mRNA expression and Period 2 protein content, with a minimum at lights-off, and a maximum at lights-on (Gaszner et al., 2009b). We furthermore found a diurnal rhythm in the number of Ucn1-immunopositive neurons and in their $U \mathrm{cn} 1$ peptide content, with a minimum at night and at the beginning of the light period and a peak at lights-off, while calcium ion; $C R F$, corticotropin-releasing factor; $D_{2}$, dopamine $D_{2}$ receptor; $D A$, dopamine; $\mathrm{G}_{\mathrm{a}^{\prime}} \mathrm{GABA}_{\mathrm{A}}$ receptor; $\mathrm{G}_{\mathrm{b}^{\prime}}, \mathrm{GABA}_{\mathrm{B}}$ receptor; $\mathrm{GABA}, \gamma$-aminobutyric acid; $\mathrm{M}$, mesotocin receptor; $\mathrm{M} 1$, muscarinic $\mathrm{M} 1$ receptor; $\mathrm{ME}$, metenkephalin; $\mathrm{Me}$, metenkephalin receptor; MT, mesotocin; NA, noradrenalin; NPY, neuropeptide Y; P, P75 ${ }^{\text {NTR }}$ receptor; PACAP, pituitary adenylyl cyclase-activating polypeptide; T, TrkB receptor; T3, thyrotropin-releasing hormone receptor 3; $\mathrm{TRH}$, thyrotropinreleasing hormone; Ucn1, urocortin 1; V1, VPAC1 receptor; Y1, NPYY, receptor. (Modified after Roubos et al., 2005.) the Ucn 1 mRNA content paralleled the Period 2 mRNA rhythm. These rhythms in the rat npEW are accompanied by a diurnal rhythm in plasma corticosterone concentration. Diurnal production of Period 2 and Ucn 1 in the npEW may be relevant for the maintenance of the known diurnal rhythm in the stress response (Gaszner et al., 2009b).

\section{UCN1 AND STRESS}

Besides CRF-neurons in the hypothalamic paraventricular nucleus (PVN), Ucn1-neurons in the npEW seem to be main neural players in the regulation of stress adaptation. They are recruited by various acute stressors (Weninger et al., 2000; Gaszner et al., 2004; Korosi et al., 2005; Kozicz, 2007b) as well as by chronic stressors (Korosi et al., 2005, 2008a; Gaszner et al., 2009a), and their Ucn1 mRNA expression is upregulated by acute pain and restraint stress (Weninger et al., 2000; Kozicz, 2007b). Nevertheless, the dynamics of npEW-Ucn1 neurons strongly differ from PVN-CRF neurons (Weninger et al., 2000). In PVN neurons, a rapid and almost maximal increase in cFos expression occurs after a single $30 \mathrm{~min}$ episode of acute restraint, whereas npEW-Ucn1 neurons never respond to stressful stimuli within an hour (Viau and Sawchenko, 2002). Instead, their activation peaks $2-4 \mathrm{~h}$ after the challenge and 
is maintained for up to $18 \mathrm{~h}$ (Gaszner et al., 2004; Kozicz, 2007b). Furthermore, in CRF-over-expressing mice (Dirks et al., 2002), npEW-Ucn1 mRNA is strongly downregulated (Kozicz et al., 2004) whereas in CRF-null mice this mRNA is upregulated (Weninger et al., 2000). Also, we demonstrated that the response of the npEWUcn 1 system to a chronic stressor does not habituate (Korosi et al., 2005), which is in contrast with the habituating chronic stress response of the HPA-axis (Viau and Sawchenko, 2002).

The data outlined above have raised the possibility that the PVNCRF and the npEW-Ucn 1 neuronal systems comprise two distinct but functionally interrelated entities that are co-ordinately regulated by acute stressors but inversely respond to chronic stress (Kozicz, 2007b). Possibly, the two systems possess complementary dynamics that serve to adequately terminate the central stress response. Such collaboration suggests a very important role of npEW-Ucn 1 neurons in stress adaptation and, as a consequence, in stress-related disorders like anxiety, major depression and use of drugs of abuse (Kozicz, 2007b).

\section{UCN1 AND ANXIETY}

Urocortin-deficient mice show increased anxiety-like behavior (Vetter et al., 2002). Ucn 1 mRNA expression in the npEW is increased in response to various acute stressors (Weninger et al., 2000; Gaszner et al., 2004; Kozicz, 2007b) and in CRF-deficient mice (Weninger et al., 2000). Furthermore, the npEW is activated by systemic administration of the metabotropic glutamate (mGLU) receptor agonist, LY354740, and this activation is absent in mGlu2knockout mice (Linden et al., 2004). These findings indicate that mGLU receptors modulate neuronal excitability in the npEW in relation to anxiogenesis (Skelton et al., 2000; Gysling et al., 2004), a notion supported by the finding that Ucn 1 and CART in npEW neurons are recruited by acute lipopolysaccharide stress (Kozicz, 2003). Since in rodents intracerebroventricular injection of CART, which co-exist with Ucnl in the npEW, enhances anxiety-like behavior, CART-Ucn1-positive npEW neurons may modulate this behavior (Kask et al., 2000; Asakawa et al., 2001).

Also NPY, a possible regulator of the state of anxiety (Thorsell et al., 1999; Kask et al., 2002), may play a role in the modulation of anxiety behavior by npEW-Ucn 1 neurons because in animals exposed to stress, not only Ucn 1 mRNA but also NPY mRNA expression in npEW-neurons is strongly affected (Thorsell et al., 1999). Moreover, NPY axons seem to contact these neurons in both rodents and human (Gaszner et al., 2007). Therefore, NPY inputs to npEW neurons may be involved in governing stress-induced anxiety in rodents and men.

\section{THE NPEW AND PAIN}

Acute pain triggers an organism to avoid harmful situations (Millan, 1999) and coincides with an activation of the HPA-axis, as revealed by increased blood titers of adrenocotricotropic hormone (ACTH) and cortisol or corticosterone (Makara et al., 1969; Taylor et al., 1998; Greisen et al., 1999) but central adaptive mechanisms to pain are not fully understood. A possible mediator in adaptation to pain is the doublecortin-like kinase gene, $d c l k$, which gives rise to DCLK-short and DCLK-long. Since DCLK contains a conserved MAPK-PTSP phosphorylation site and pain activates MAPK pathways (Ji and Woolf, 2001), recently its possible involvement in the pain-stress response by the PVN and npEW was tested. This revealed that both DCLK-short and DCLK-long are present in parvocellular neurons of the PVN and in Ucn1-neurons of the npEW. Upon an acute pain stimulus, DCLK-long, but not DCLK-short, is phosphorylated in the npEW but remains unaffected in the PVN. Apparently, pain differentially affects DCLK-long-mediated neuronal plasticity in these two stress-sensitive brain centers (Rouwette et al., 2010).

\section{THE NPEW AND ALCOHOL CONSUMPTION}

A possible role of npEW-Ucn1 neurons in the development of maladaptation stress leading to addiction is indicated by the finding that these neurons are sensitive to alcohol and that experimental manipulation of the npEW-Ucn1 system affects alcohol preference and consumption (Ryabinin and Weitemier, 2006). Moreover, a positive correlation exists between the amount of Ucn 1 in the npEW and the degree of alcohol preference and consumption (Bachtell et al., 2002, 2003; Ryabinin and Weitemier, 2006). Since stress experiences increase the propensity of an individual to develop drug self-administration behavior (Piazza and Le Moal, 1998), stress-induced activation of the npEW may be a key event in the development of alcoholism.

\section{THE NPEW AND FEEDING}

Leptin informs the brain about the level of fat storage in adipose tissue, and is critical for the central control of food intake and energy metabolism (Sánchez-Lasheras et al., 2010). Fasting rats for 2 days causes a marked body weight loss, reduces the leptin plasma titer, and upregulates the amount of Ucn 1 mRNA and CART mRNA in the rat npEW by 3.3 and 2.4 times, respectively (Xu et al., 2009). PCR has revealed mRNAs of both leptin receptor (ObR) long and short forms in the npEW (Xu et al., 2009). Double-labeling immunocytochemistry has shown leptin receptors in rat npEW-Ucn 1 neurons using an antiserum not distinguishing between short and long ObR. Recently, the long form (ObRb) has been specified in npEW-Ucn1 neurons of ObRb-GFP mouse (L. Xu, personal communication). Furthermore, these neurons respond to leptin administration with activation of the JAK2-STAT3 pathway, both in vivo and in vitro, while in $\mathrm{db} /$ $\mathrm{db}$ (deficient leptin signaling) mice the amount of Ucn 1 in the $n p E W$ is considerably reduced. Patch clamping revealed that leptin inhibits the electrical activity of npEW neurons. Apparently, ObRb-expressing npEW-Ucn 1 neurons sense both stress- and metabolism-related cues, which is consistent with the idea that these cells represent an extrahypothalamic mechanism that links energy homeostasis to neuronal circuitries controlling stress adaptation (Xu et al., 2009; L. Xu, personal communication). In this respect it is noteworthy that the npEW-Ucn 1 neurons in rodents also contain the "eating peptides" CART and nesfatin-1 (Xu et al., 2009, 2010; Okere et al., 2010). Acute (restraint) stress stimulates the general secretory activity of mouse npEW-Ucn 1 neurons (increased presence of cFos) and increases the amounts of Ucn 1 , CART and nesfatin mRNAs compared to controls, by $\times 1.8, \times 2.0$, and $\times 2.6$, respectively (Okere et al., 2010). Since Ucn 1 , CART and nesfatin- 1 are established feeding regulatory factors, these data favor the idea that the npEW in rodents plays a role in the co-ordination of stress adaptation and feeding control (Okere et al., 2010; Xu et al., 2010). 


\section{THE NPEW AND GENDER-SPECIFIC ADAPTIVE RESPONSES}

The above-mentioned increase in npEW Ucn 1 mRNA and CART mRNA after fasting only takes place in male rats, whereas females do not show a reaction of the npEW (Xu et al., 2009). This suggests that the npEW acts in a gender-specific way, an idea strongly supported by the finding that $\operatorname{Er} \beta$, but not ER $\alpha$ receptors, co-exist with Ucn1 the mouse npEW (Derks et al., 2007). As estrogen decreases transcriptional activity of the Ucn 1 promoter via $\operatorname{Er} \beta$ (Haeger et al., 2005), npEW-Ucn1 neurons may play a role in the gender differences in stress sensitivity in rodents and possibly in humans as well. Although an increased susceptibility of females to depression has been well documented (Kornstein, 1997; Frackiewicz et al., 2000; Kudielka and Kirschbaum, 2005), the underlying mechanism is unclear. Possibly, gender-specific actions of npEW-Ucn 1 neurons account for this difference. This idea is in line with the finding that, under basal, unstressed conditions, the amount of Ucn 1 mRNA in the npEW does not differ between male and female mice whereas chronic variable mild stress (CVM) does increase Ucn 1 mRNA in males but not in females (B. Gaszner, personal communication). The same phenomenon was found in humans, where Ucn 1 mRNA appeared to be strongly upregulated in male suicide victims with major depression but no such upregulation was observed in female suicides (Kozicz et al., 2008b). In the rat npEW, Ucn1 mRNA showed sex-dependent expression already under basal conditions, with Ucn 1 mRNA expression higher in males than in females. In contrast to Ucn1, no changes were seen for BDNF mRNA, but BDNF protein was more abundant in males than in females (B. Gaszner, personal communication). In humans, however, BDNF mRNA did differ between the sexes, with control females having more BDNF mRNA (Kozicz et al., 2008b).

Like BDNF mRNA, in the rat CART mRNA does not reveal a sex difference but CART peptide is more abundant in males. In humans, CART mRNA does also not differ between males and females, and is equally upregulated in male and female suicides ( $\mathrm{L}$. Xu, personal communication). The data obtained for basal Ucn1, BDNF, and CART dynamics, for Ucn 1 in response to CVM, and for Ucn 1 and BDNF during major depression, strongly indicate that the npEW plays a role in the development of major depression in a sex-dependent manner.

The presence of the endocannabinoid receptor, $\mathrm{CB} 1$, in the mouse npEW strongly implies modulation of the nucleus' activity by endocannabinoids signaling. Indeed, npEW-Ucn 1 mRNA is lower in male CB1-knockout mice than in male wildtype mice. This supports the hypothesis of an inverse relationship between the CRF- and Ucn 1-containing neuronal systems in chronic situations (Weninger et al., 1999; Skelton et al., 2000; Kozicz, 2007b). However, this difference is not present in females, indicating that CB1-knockout mice and wildtypes differ sex-dependently in their npEW dynamics. Moreover, the two genotypes seem to respond differently to restraint stress compared to CVM stress, because Ucn 1 in wildtypes only increase upon CVM stress, while in $\mathrm{CB} 1-/-\mathrm{Ucn} 1$ increases only upon restraint stress. In view of these data, the mouse endocannabinoid signaling system may modulate the npEW in a sex-dependent manner (Derks, 2010).

\section{A MODEL OF ADAPTATION AND MALADAPTATION}

On the basis of the data mentioned above we have constructed a model of the possible interactions between the PVN and the npEW, and of the role the npEW plays in the stress response, related behaviors, and the development of major depression (Derks, 2010; Figure 3).

In this model, which represents the male situation, in response to a stressor the limbic system does not only activate the HPA-axis but at the same time also the npEW, via NPY. The npEW-Ucn1 neurons contain glucocorticoid receptors and their Ucn 1 dynamics are affected by glucocorticoid administration (T. Kozicz, personal communication). In addition to inputs from the limbic system and the HPA-axis, npEW-Ucn1 neurons most likely receive orexinergic input from the lateral hypothalamus (Baldo et al., 2003), serotonergic input from the dorsal raphe nucleus (T. Kozicz, personal communication) and GABA-ergic input from npEW interneurons that contain CB1 receptors (Derks, 2010). Finally, the npEW-Ucn1 neurons are under control of leptin (L. Xu, personal communication) released from white adipose tissue into the circulation.

In our model we distinguish chronic non-variable stressors and chronic variable stressors, which evoke different npEW responses. The npEW-Ucn 1 contents habituate, i.e., return to normal, unstressed conditions, after chronic homeotypic stress (Korosi et al., 2005) but not after CMV stress (Derks, 2010). It is hypothesized that during chronic non-variable stress inputs from the various brain centers decrease the production of endocannabinoids in npEW-Ucn1 neurons and, consequently, reduce the inhibitory feedback of these neurons to GABA-ergic npEWinterneurons. Consequently, presynaptic inhibition is alleviated and the interneurons start to inhibit npEW-Ucnl activity. We propose that, in contrast, during chronic variable stress the endocannabinoid inhibition of the GABA-ergic interneurons remains high. As a consequence, npEW-Ucn1 neurons remain active, resulting in strong Ucn 1 output to the npEW target areas, viz. the dorsal raphe and the lateral septum. Changes in npEW-Ucn 1 dynamics may have an effect on the activity of the HPA-axis by controlling these two centers. Ucn 1 secretion may therefore increase neuronal activity in the dorsal raphe by binding CRFR2 receptors (Valentino and Commons, 2005) and in this way protect against major depression. A similar mechanism may hold for the lateral septum, where Ucn1 can modulate anxiety-like and depression-like behavior via CRFR2 (Van Pett et al., 2000).

Basically, this model does not only hold for males but also for females if an additional regulatory factor is implemented: estrogen. Upon binding estrogen, the ER $\beta$ receptor in the npEW-Ucn1 neurons may inhibit $U c n 1$ secretion in a similar way as it inhibits CRF release from the PVN (Hauger et al., 2006). This idea is supported by our observations of low npEW-Ucn 1 secretory activity in unstressed female rats (Derks et al., 2010) as well as in stressed female mice (Derks, 2010). Lower npEW activity will diminish Ucn1 output to the dorsal raphe and the lateral septum, and in this way modulate activities in these brain areas. This sequence of events may be the cause of the increased risk of females to develop major depression.

In addition to Ucn1, the possible roles of BDNF and CART in the sex-dependent stress response have been implemented into the model. As the secretory dynamics of both BDNF and CART in the npEW are inhibited by estrogen, we propose that upon activation of the 


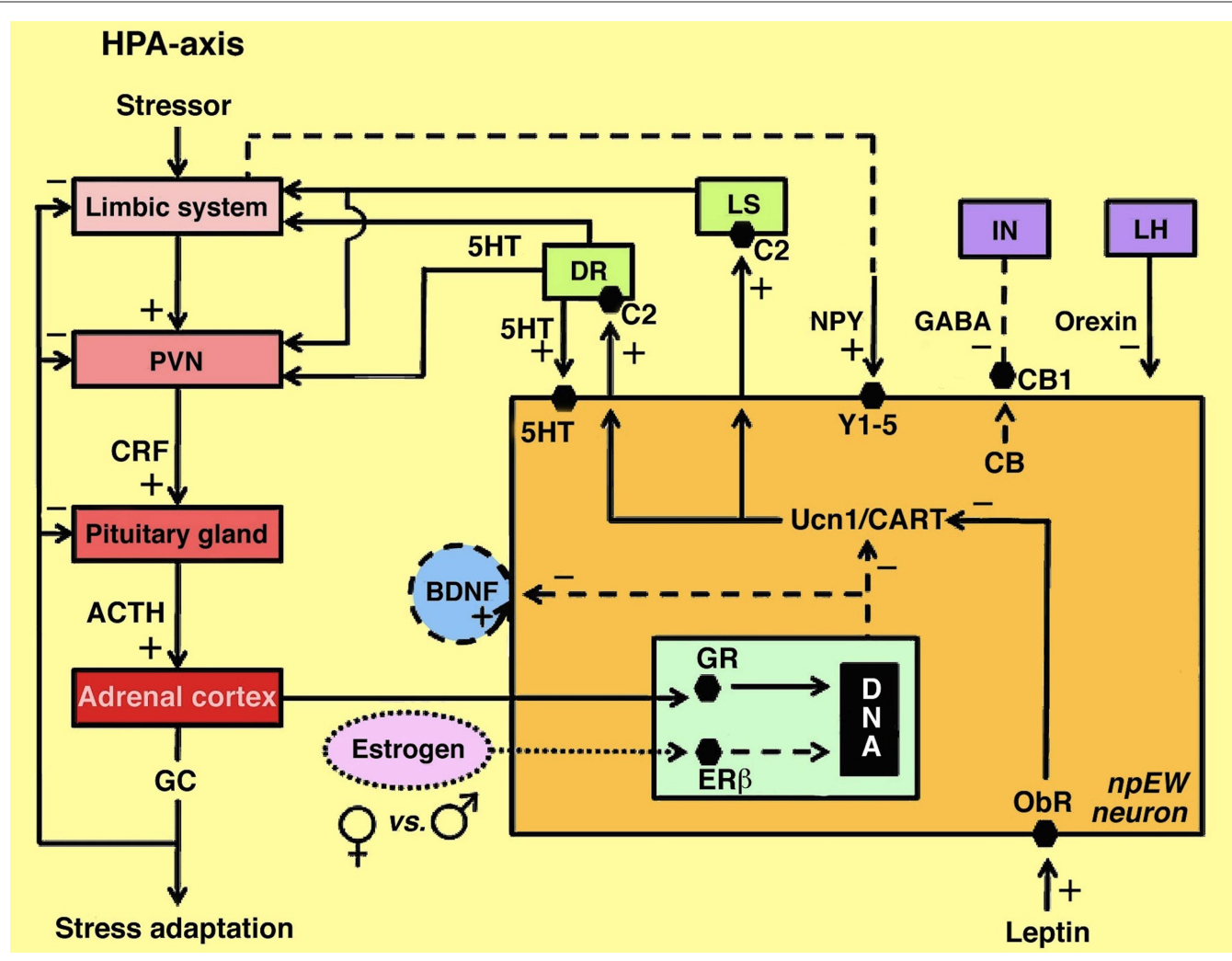

FIGURE 3 | Model of interactions between the npEW and the HPA-axis and other centers involved in stress adaptation and energy metabolism.

Continuous lines indicate established interactions, dashed lines indicate presumed interactions; the dotted line refers to sex difference. $5 \mathrm{HT}$, serotonin; $\mathrm{ACTH}$, adrenocorticotrope hormone; BDNF, brain-derived neurotrophic factor; $\mathrm{C} 2$, corticotropin-releasing factor receptor 2; CART, cocaine- and amphetamine-regulated transcript peptide; $C B$, endocannabinoids; $C B 1$, endocannabinoid receptor 1; $C R F$, corticotropin-releasing factor; $\mathrm{DR}$, dorsal raphe nucleus; $E R \beta$, estrogen receptor $\beta$; GABA, $\gamma$-aminobutyric acid; GC, glucocorticoids; GR, glucocorticoid receptor; IN, interneuron; LH, lateral hypothalamus; LS, lateral septum; NPY, neuropeptideY; $\mathrm{ObR}$, leptin receptor; PVN, paraventricular nucleus; Ucn1, urocortin $1 ; \mathrm{Y}-1 / 5$; neuropeptide Y receptors 1 and 5. (Slightly modified after Derks, 2010.)
npEW, BDNF is released to stimulate the activity of npEW-neurons in an autoexcitatory, paracrine way. Whereas autoexcitatory actions of neuropeptides have been well-established in other neural systems such as in the CDC of Lymnaea and, more specifically, for BDNF in the melanotropes of Xenopus laevis (Kramer et al., 2002a), an autocrine action of BDNF on npEW neurons is hypothetical. CART is present in the same secretory vesicles as Ucn1 (Van Wijk et al., 2009) and will therefore be released simultaneously with $U \mathrm{cn} 1$, possibly acting on the same targets. Most likely, CART actions on the HPA-axis, dorsal raphe, and lateral septum may be physiologically different from those of Ucn1, but this has to be established further. In this respect, the notion that CART is not only involved in the stress response but also plays a role in food intake and drug reward (Smith et al., 1995; Couceyro et al., 1997; Koylu et al., 2006) may be of relevance. Similarly, the eating peptide nesfatin-1 may contribute to a role of the npEW in coordinating stress adaptation and feeding behaviors (Okere et al., 2010; Xu et al., 2010).

\section{FINAL CONSIDERATIONS}

In this review we have considered data obtained from studying three animal models on the functioning of the neural cell in adaptive behaviors. The neurosecretory CDC show how one cell (type) can co- ordinate a complex adaptive behavior, egg-laying on the most suitable place and time. The neuroendocrine melanotrope cell is an example of a neural cell that receives and integrates various environmental stimuli and translates them into a meaningful adaptive response, the adjustment of skin pigmentation for optimal camouflage. The npEW, finally, demonstrates how the integrative and regulatory capacities like those revealed by the CDC and the melanotropes, permit a complex midbrain center to integrate multiple external and internal stimuli to co-ordinate different complex but related behaviors (stress adaptation, feeding activity) and how dysregulation of this co-ordination may cause brain disorders like major depression and alcoholism. While awaiting new technological developments to study the living human brain at the neuron and subneuronal level, continuing progress may be expected from neuroscientific research on invertebrate and vertebrate animal model systems.

\section{ACKNOWLEDGMENTS}

The authors wish to thank Sjoerd Wendelaar Bonga for critical reading of the text. This review is dedicated to the memory of Joos Joosse (1930-2010), a most inspirational biologist and endocrinologist. It was supported by grant \#864.05.008 from the Netherlands Organization for Scientific Research, NWO, to Tamás Kozicz. 


\section{REFERENCES}

Asakawa, A., Inui,A., Yuzuriha, H., Nagata, T., Kaga, T., Ueno, N., Fujino, M. A., and Kasuga, M. (2001). Cocaineamphetamine-regulated transcript influences energy metabolism, anxiety and gastric emptying in mice. Horm. Metab. Res. 33, 554-558.

Audesirk, G., and Strumwasser, F. (1975). Circadian rhythm of neuron R15 of Aplysia californica: In vivo photoentrainment. Proc. Natl. Acad. Sci. U. S. A. 72, 2408-2412.

Ayoubi,T.A.,Jenks,B.G., Roubos,E.W., and Martens, G. J. (1992). Transcriptional and posttranscriptional regulation of the proopiomelanocortin gene in the pars intermedia of the pituitary gland of Xenopus laevis. Endocrinology 130, 3560-3566.

Bachtell, R. K., Tsivkovskaia, N. O., and Ryabinin, A. E. (2002). Strain differences in urocortin expression in the Edinger-Westphal nucleus and its relation to alcohol-induced hypothermia. Neuroscience 113, 421-434.

Bachtell, R. K., Weitemier, A. Z., GalvanRosas, A., Tsivkovskaia, N. O., Risinger, F. O., Phillips, T. J., Grahame, N. J., and Ryabinin, A. E. (2003). The EdingerWestphal-lateral septum urocortin pathway and its relationship to alcohol consumption. J. Neurosci. 23, 2477-2487.

Baldo, B. A., Daniel, R. A., Berridge, C. W., and Kelley, A. E. (2003). Overlapping distributions of orexin/hypocretinand dopamine-beta-hydroxylase immunoreactive fibers in rat brain regions mediating arousal, motivation, and stress. J. Comp. Neurol. 464, 220-237.

Benjamin, P. R. (2008). Lymnaea. Scholarpedia, 3, 4124. revision \#73236. http://www.scholarpedia.org/wiki/ index.php?title=Lymnaea\&\&oldid $=$ 46855.

Berghs, C. A., Korteweg, N., Bouteiller, A., Tuinhof, R., Asbreuk, C., Verhage, M., and Roubos, E. W. (1999). Co-expression in Xenopus neurons and neuroendocrine cells of messenger RNA homologues of exocytosis proteins DOC2 and munc18-1. Neuroscience 92, 763-772.

Berghs, C. A., and Roubos, E. W. (1996). Background adaptation and synapse plasticity in the pars intermedia of Xenopus laevis. Neuroscience 70, 833-841.

Berghs, C. A., Tanaka, S., and Roubos, E. W. (1998). Neuroendocrine responses in background adaptation. Ann. N. Y. Acad. Sci. 839, 574-575.

Berghs, C. A., Tanaka, S., Van Strien, F. J., Kurabuchi, S., and Roubos, E. W. (1997). The secretory granule and pro-opiomelanocortin processing in Xenopus melanotrope cells during background adaptation. J. Histochem. Cytochem. 45, 1673-1682.

Bidaud, I., Galas, L., Bulant, M., Jenks, B. G., Ouwens, D. T., Jegou, S., Ladram, A., Roubos, E. W., Tonon, M. C., Nicolas, P., and Vaudry, H. (2004). Distribution of the mRNAs encoding the thyrotropin-releasing hormone (TRH) precursor and three TRH receptors in the brain and pituitary of Xenopus laevis: effect of background color adaptation on TRH and TRH receptor gene expression. J. Comp. Neurol. 477, 11-28.

Bijlsma, R., and Loeschcke, V. (2005). Environmental stress, adaptation and evolution: an overview. J. Evol. Biol. 18, 744-749.

Bittencourt, J. C., Vaughan, J., Arias, C., Rissman, R. A., Vale, W. W., and Sawchenko, P. E. (1999). Urocortin expression in rat brain: evidence against a pervasive relationship of urocortin-containing projections with targets bearing type 2 CRF receptors. J. Comp. Neurol. 415, 285-312.

Blomqvist, A. G., Roubos, E. W., Larhammar, D., and Martens, G. J. (1995). Cloning and sequence analysis of a neuropeptide Y/peptide YY receptor Y1 cDNA from Xenopus laevis. Biochim. Biophys. Acta 1261, 439-441.

Boeke, J. D. (2004). Evolution: A is for adaptation. Nature 431, 408-409.

Boer, H.H. (1965). A cytological and cytochemical study of neurosecretory cells in Basommatophora, with particular reference to Lymnaea stagnalis L. Arch. Neérl. Zool, 16, 343-386.

Boer, H. H., Groot, C., De Jong-Brink, M., and Cornelisse, C. . J. (1976). Polyploidy in the freshwater snail Lymnaea stagnalis (Gastropoda, Pulmonata). A cytophotometric analysis of the DNA in neurons and some other cell types. Neth. J. Zool. 27, 245-252.

Boer, H. H., Schot, L.P., Roubos, E. W., Ter Maat,A., Lodder,J.C., Reichelt, D., and Swaab, D. F. (1979). ACTH-like immunoreactivity in two electronically coupled giant neurons in the pond snail Lymnaea stagnalis. Cell Tissue Res. 202, 231-240.

Boer, H. H., Slot, J. W., and Van Andel, J. (1968). Electron microscopical and histochemical observations on the relation between medio-dorsal bodies and neurosecretory cells in the basommatophoran snails Lymnaea stagnalis, Ancylus fluviatilis, Australorbis glabratus and Planorbarius corneus. Z. Zellforsch. Mikrosk. Anat. 87, 435-450.

Bridle, J.R., and Vines, T. H. (2007). Limits to evolution at range margins: when and why does adaptation fail? Trends Ecol. Evol. 22, 140-147.
Brink, M., and Boer, H. H. (1967). An electron microscopical investigation of the follicle gland (cerebral gland) and of some neurosecretory cells in the lateral lobe of the cerebral ganglion of the pulmonate gastropod Lymnaed stagnalis L.Z.Zellforsch. Mikrosk. Anat. 79, 230-243.

Brussaard,A. B., Schluter, N. C., Ebberink, R. H., Kits, K. S., and TER Maat, A (1990). Discharge induction in molluscan peptidergic cells requires a specific set of autoexcitatory neuropeptides. Neuroscience 39, 479-491.

Buma, P., and Roubos, E. W. (1983). Calcium dynamics, exocytosis, and membrane turnover in the ovulation hormone-releasing caudo-dorsal cells of Lymnaea stagnalis. Cell Tissue Res. 233, 143-159.

Buma, P., and Roubos, E. W. (1986). Ultrastructural demonstration of nonsynaptic release sites in the central nervous system of the snail Lymnaea stagnalis, the insect Periplaneta americana, and the rat. Neuroscience 17 867-879.

Buma, P., Roubos, E. W., and Buijs, R. M. (1984). Ultrastructural demonstration of exocytosis of neural, neuroendocrine and endocrine secretions with an in vitro tannic acid (TARI-) method. Histochemistry 80, 247-256.

Burde, R. M., Parelman, J. J., and Luskin, M. (1982). Lack of unity of EdingerWestphal nucleus projections to the ciliary ganglion and spinal cord: a double-labeling approach. Brain Res. 249, 379-382.

Burgers, A. C. (1956). On the influence of adrenaline and an adrenaline-like compound on the melanophore activity of Xenopus laevis. Acta Physiol. Pharmacol. Néerl. 5, 225-226.

Burgers, A. C., Imai, K., and Van Oordt, G. J. (1963). The amount of melanophore-stimulating hormone in single pituitary glands of Xenopus laevis kept under various conditions. Gen. Comp. Endocrinol. 3, 53-57.

Burgers, A. C., and Van Oordt, G. J. (1962). Regulation of pigment migration in the amphibian melanophore. Gen. Comp. Endocrinol. Suppl. 1, 99-109.

Buzzi, M., Bemelmans, F. F., Roubos, E. W., and Jenks, B. G. (1997) Neuroendocrine gamma-aminobutyric acid (GABA): functional differences in $G_{A B A}$ versus $G_{A B A}$ receptor inhibition of the melanotrope cell of Xenopus laevis. Endocrinology 138, 203-212.

Calle, M., Corstens, G. J., Wang, L., Kozicz, T., Denver, R. J., Barendregt, H. P., and Roubos, E. W. (2005). Evidence that urocortin I acts as a neurohormone to stimulate alpha MSH release in the toad Xenopus laevis. Brain Res. 1040 14-28.
Calle, M., Jenks, B. G., Corstens, G. J., Veening, J. G., Barendregt, H. P., and Roubos, E. W. (2006a). Localisation and physiological regulation of corticotrophin-releasing factor receptor 1 mRNA in the Xenopus laevis brain and pituitary gland. J. Neuroendocrinol. 18 , 797-805.

Calle, M., Kozicz, T., Van Der Linden, E. Desfeux, A., Veening, J. G., Barendregt, H.P., and Roubos, E. W. (2006b). Effect of starvation on Fos and neuropeptide immunoreactivities in the brain and pituitary gland of Xenopus laevis. Gen. Comp. Endocrinol. 147, 237-246.

Calle, M., Wang, L., Kuijpers, F. J., Cruijsen, P. M., Arckens, L., and Roubos, E. W. (2006c). Brain-derived neurotrophic factor in the brain of Xenopus laevis may act as a pituitary neurohormone together with mesotocin. $J$ Neuroendocrinol. 18, 454-465.

Cavani, J. A., Reiner, A., Cuthbertson, S. L., Bittencourt, J. C., and Toledo, C. A. (2003). Evidence that urocortin is absent from neurons of the EdingerWestphal nucleus in pigeons. Braz. J. Med. Biol. Res. 36, 1695-1700.

Clements, J. R., Beitz, A. J., Fletcher, T. F., and Mullett, M. A. (1985). Immunocytochemical localization of serotonin in the rat periaqueductal gray: a quantitative light and electron microscopic study. J. Comp. Neurol. 236, 60-70.

Corstens, G. J., Van Boxtel, R., Van den Hurk, M. J., Roubos, E. W., and Jenks, B. G. (2006). The effects of disruption of A kinase anchoring protein-protein kinase $\mathrm{A}$ association on protein kinase A signalling in neuroendocrine melanotroph cells of Xenopus laevis. J. Neuroendocrinol. 18, 477-483.

Couceyro, P. R., Koylu, E. O., and Kuhar, M. J. (1997). Further studies on the anatomical distribution of CART by in situ hybridization. J. Chem. Neuroanat. 12, 229-241,

De Jong-Brink, M., Elsaadany, M. M., and Boer, H. H. (1988). Schistosomin, an antagonist of calfluxin. Exp. Parasitol. $65,109-118$.

De Rijk, E. P., Jenks, B. G., Vaudry, H., and Roubos, E. W. (1990a). GABA and neuropeptide $\mathrm{Y}$ co-exist in axons innervating the neurointermediate lobe of the pituitary of Xenopus laevis-an immunoelectron microscopic study. Neuroscience 38, 495-502.

De Rijk, E. P., Jenks, B. G., and Wendelaar Bonga, S. E. (1990b). Morphology of the pars intermedia and the melanophore-stimulating cells in Xenopus laevis in relation to background adaptation. Gen. Comp. Endocrinol. 79, 74-82.

De Rijk, E. P., Van Strien, F. J., and Roubos, E. W. (1992). Demonstration of coexisting catecholamine (dopamine), 
amino acid (GABA), and peptide (NPY) involved in inhibition of melanotrope cell activity in Xenopus laevis: a quantitative ultrastructural, freezesubstitution immunocytochemical study. J. Neurosci. 12, 864-871.

De Vlieger, T. A., Kits, K. S., Ter Maat, A., and Lodder, J. C. (1980). Morphology and electrophysiology of the ovulation hormone producing neuroendocrine cells of the freshwater snail Lymnaea stagnalis (L.). J. Exp. Biol. 84, 259-271.

Deen, P. M., Bussemakers, M. J., Terwel, D., Roubos, E. W., and Martens, G. J. (1992). Comparative structural analysis of the transcriptionally active proopiomelanocortin genes $\mathrm{A}$ and $\mathrm{B}$ of Xenopus laevis. Mol. Biol. Evol. 9 , 483-494.

Derks, N. M. (2010). The Role of the Non-Preganglionic Edinger-Westphal Nucleus in Sex-Dependent Stress Adaptation in Rodents. Ph.D. thesis, Radboud University Nijmegen, Nijmegen, 112 p.

Derks, N. M., Gaszner, B., Roubos, E. W., and Kozicz, L. T. (2010). Sex differences in urocortin 1 dynamics in the non-preganglionic Edinger-Westphal nucleus of the rat. Neurosci. Res. 66, 117-123.

Derks, N. M., Roubos, E. W., and Kozicz, T. (2007). Presence of estrogen receptor beta in urocortin 1-neurons in the mouse non-preganglionic EdingerWestphal nucleus. Gen. Comp. Endocrinol. 153, 228-234.

Dictus, W. J., De Jong-Brink, M., and Boer, H. H. (1987). A neuropeptide (calfluxin) is involved in the influx of calcium into mitochondria of the albumen gland of the freshwater snail Lymnaea stagnalis. Gen. Comp. Endocrinol. 65, 439-450.

Dirks, A., Groenink, L., Bouwknecht, J. A., Hijzen, T. H., Van Der Gugten, J., Ronken, E., Verbeek, J. S., Veening, J. G., Dederen, P. J., Korosi, A., Schoolderman, L. F., Roubos, E. W., and Olivier, B. (2002). Overexpression of corticotropin-releasing hormone in transgenic mice and chronic stress-like autonomic and physiological alterations. Eur. J. Neurosci. 16, 1751-1760.

Dogterom, G. E., Hofs, H. P., Wapenaar, P., Roubos, E. W., and Geraerts, W. P. (1984a). The effect of temperature on spontaneous, and ovulation hormone-induced female reproduction in Lymnaea stagnalis. Gen. Comp. Endocrinol. 56, 204-209.

Dogterom, G. E., Van Loenhout, H., Koomen, W., Roubos, E. W., and Geraerts, W. P. (1984b). Ovulation hormone, nutritive state, and female reproductive activity in Lymnaea stagnalis. Gen. Comp. Endocrinol. 55, 29-35.
Dotman, C. H., Van Herp, F., Martens, G. J., Jenks, B. G., and Roubos, E. W. (1998). Dynamics of proopiomelanocortin and prohormone convertase 2 gene expression in Xenopus melanotrope cells during long-term background adaptation. J. Endocrinol. 159, 281-286.

Dun, S. L., Brailoiu, G. C., Mizuo, K., Yang, J., Chang, J. K., and Dun, N. J. (2005). Neuropeptide B immunoreactivity in the central nervous system of the rat. Brain Res. 1045, 157-163.

Eagleson, G. W., Van Der Heijden, R. A., Roubos, E. W., and Jenks, B. G. (2010). A developmental analysis of periodic albinism in the amphibian Xenopus laevis. Gen. Comp. Endocrinol. 168, 302-306.

Ebberink, R. H., Van Loenhout, H., Geraerts, W. P., and Joosse, J. (1985) Purification and amino acid sequence of the ovulation neurohormone of Lymnaea stagnalis. Proc. Natl. Acad. Sci. U.S.A. 82, 7767-7771.

Edinger, L. (1885). Über den Verlauf der centralen Hirnnervenbahnen mit Demonstrationen von Präparaten. Arch. Psychiat. Nervenkr. (Berlin), 16, 858-889.

Frackiewicz, E. J., Sramek, J. J., and Cutler, N. R. (2000). Gender differences in depression and antidepressant pharmacokinetics and adverse events. Ann. Pharmacother. 34, 80-88.

Galas, L., Bidaud, I., Bulant, M., Jenks, B. G., Ouwens, D. T., Jegou, S., Ladram, A., Roubos, E. W., Nicolas, P., Tonon, M. C., and Vaudry, H. (2005). In situ hybridization localization of TRH precursor and TRH receptor mRNAs in the brain and pituitary of Xenopus laevis. Ann. N. Y. Acad. Sci. 1040 95-105.

Galas, L., Raoult, E., Tonon, M. C., Okada, R., Jenks, B. G., Castano, J. P., Kikuyama, S., Malagon, M., Roubos, E. W., and Vaudry, H. (2009). TRH acts as a multifunctional hypophysiotropic factor in vertebrates. Gen. Comp. Endocrinol. 164, 40-50.

Gaszner, B., Csernus, V., and Kozicz, T. (2004). Urocortinergic neurons respond in a differentiated manner to various acute stressors in the EdingerWestphal nucleus in the rat. J. Comp. Neurol. 480, 170-179.

Gaszner, B., Jensen, K. O., Farkas, J., Reglodi, D., Csernus, V., Roubos, E. W., and Kozicz, T. (2009a). Effects of maternal separation on dynamics of urocortin 1 and brain-derived neurotrophic factor in the rat non-preganglionic Edinger-Westphal nucleus. Int. J. Dev. Neurosci. 27, 439-451.

Gaszner, B., Van Wijk, D. C., Korosi, A., Jozsa, R., Roubos, E. W., and Kozicz, T. (2009b). Diurnal expression of period 2 and urocortin 1 in neurones of the non-preganglionic EdingerWestphal nucleus in the rat. Stress $12,115-124$.

Gaszner, B., Korosi, A., Palkovits, M., Roubos, E. W., and Kozicz, T. (2007). Neuropeptide $\mathrm{Y}$ activates urocortin 1 neurons in the nonpreganglionic Edinger-Westphal nucleus. J. Comp. Neurol. 500, 708-719.

Geraerts, W. P., and Bohlken, S. (1976). The control of ovulation in the hermaphroditic freshwater snail Lymnaea stagnalis by the neurohormone of the caudodorsal cells. Gen. Comp. Endocrinol. 28, 350-357.

Geraerts, W. P., and Joosse, J. (1975). Control of vitellogenesis and of growth of female accessory sex organs by the dorsal body hormone (DBH) in the hermaphroditic freshwater snail Lymnaea stagnalis. Gen. Comp. Endocrinol. 27, 450-464.

Geraerts, W.P., Tensen, C. P., and Hogenes, T. M. (1983). Multiple release of peptides by electrically active neurosecretory caudo-dorsal cells of Lymnaea stagnalis. Neurosci. Lett. 41, 151-155.

Goos, H. J. (1969). Hypothalamic control of the pars intermedia in Xenopus laevis tadpoles. Z. Zellforsch. Mikrosk. Anat. 97, 118-124.

Greisen, J., Hokland, M., Grofte, T., Hansen, P.O., Jensen, T.S., Vilstrup, H., and Tonnesen, E. (1999). Acute pain induces an instant increase in natural killer cell cytotoxicity in humans and this response is abolished by local anaesthesia. Br. J. Anaesth. 83, 235-240.

Gysling, K., Forray, M. I., Haeger, P., Daza, C., and Rojas, R. (2004). Corticotropin-releasing hormone and urocortin: redundant or distinctive functions? Brain Res. Brain Res Rev. 47, 116-125.

Haeger, P., Cuevas, R., Forray, M. I., Rojas, R., Daza, C., Rivadeneira, J., and Gysling, K. (2005). Natural expression of immature Ucn antisense RNA in the rat brain. Evidence favoring bidirectional transcription of the Ucn gene locus. Brain Res. Mol. Brain Res. 139, 115-128.

Hauger, R. L., Risbrough, V., Brauns, O., and Dautzenberg,F.M. (2006).Corticotropin releasing factor (CRF) receptor signaling in the central nervous system: new molecular targets. CNS Neurol. Disord. Drug Targets 5, 453-479.

Hermann, P. M., DE Lange, R. P., Pieneman, A. W., Ter Maat, A., and Jansen, R. F. (1997). Role of neuropeptides encoded on $\mathrm{CDCH}-1$ gene in the organization of egg-laying behavior in the pond snail, Lymnaea stagnalis. J. Neurophysiol. 78, 2859-2869.

Hogben, L., and Slome, D. (1931). The pigmentary effector system. VI. The dual character of endocrine co-ordi- nation in amphibian colour change. Proc. R. Soc. Lond., B, Biol. Sci. 108, 10-53.

Hogben, L. T. (1924). The Pigmentary Effector System. Edinburgh: Oliver \& Boyd.

Hopkins, C. R. (1970). Studies on secretory activity in the pars intermedia of Xenopus laevis. 3. The synthesis and release of melanocyte stimulating hormone (MSH) in vitro. Tissue Cell 2, 83-98.

Houssay, B. A., and Ungar, I. (1924). Action de l'hypophyse sur la coloration des Batraciens. CR Soc. Biol. Paris, 76, 318-320.

Hsu, S. Y., and Hsueh, A. J. (2001). Human stresscopin and stresscopinrelated peptide are selective ligands for the type 2 corticotropin-releasing hormone receptor. Nat. Med. 7, 605-611.

Innis, R. B., and Aghajanian, G. K. (1986). Cholecystokinin-containing and nociceptive neurons in rat EdingerWestphal nucleus. Brain Res. 363 , 230-238.

Jansen, R. F., and Ter Maat, A. (1985). Ring neuron control of columellar motor neurons during egg-laying behavior in the pond snail. J. Neurobiol. 16, 1-14.

Jansen, R. F., Ter Maat, A., and Bos, N. P. (1985). Membrane mechanism of neuroendocrine caudo-dorsal cell inhibition by the ring neuron in the pond snail Lymnaea stagnalis. J. Neurobiol. 16, 15-26.

Jenks, B. G. (1977). Control of MSH synthesis and release in the aquatic toad, Xenopus laevis. Front. Horm. Res. 4, 63-65.

Jenks, B. G., Buzzi, M., Dotman, C. H., DE Koning, H. P., Scheenen, W. J., Lieste, J. R., Leenders, H. J., Cruijsen, P. M., and Roubos, E.W. (1998). The significance of multiple inhibitory mechanisms converging on the melanotrope cell of Xenopus laevis. Ann. N. Y. Acad. Sci. 839, 229-234.

Jenks, B. G., Kidane, A. H., Scheenen, W. J., and Roubos, E. W. (2007). Plasticity in the melanotrope neuroendocrine interface of Xenopus laevis. Neuroendocrinology 85, 177-185.

Jenks, B. G., Meulepas, W. J., Soons, P. J., and Van Overbeeke, A. P. (1979). Biosynthesis of MSH and related peptides in the pars intermedia of the mouse: a pulse-chase analysis. Mol. Cell. Endocrinol. 13, 149-158.

Jenks, B. G., Roubos, E. W., and Scheenen, W. J. (2003). $\mathrm{Ca}^{2+}$ oscillations in melanotropes of Xenopus laevis: their generation, propagation, and function. Gen. Comp. Endocrinol. 131, 209-219.

Ji, R., and Woolf, C. J. (2001). Neuronal plasticity and signal transduction in nociceptive neurons: implications for the initiation and maintenance 
of pathological pain. Neurobiol. Dis. $8,1-10$.

Jiménez, C. R., Li, K. W., Smit, A. B., and Janse, C. (2006). Auto-inhibitory control of peptidergic molluscan neurons and reproductive senescence. Neurobiol. Aging 27, 763-769.

Jiménez, C. R., Ter Maat, A., Pieneman, A., Burlingame, A. L., Smit, A. B., and Li, K. W. (2004). Spatio-temporal dynamics of the egg-laying-inducing peptides during an egg-laying cycle: a semiquantitative matrix-assisted laser desorption/ionization mass spectrometry approach. J. Neurochem. 89 , 865-875.

Jiménez, C. R., Van Veelen, P. A., Li, K. W., Wildering, W. C., Geraerts, W. P., Tjaden, U. R., and Van Der Greef, J. (1994). Neuropeptide expression and processing as revealed by direct matrix-assisted laser desorption ionization mass spectrometry of single neurons. J. Neurochem. 62, 404-407.

Joosse, J. (1964). Dorsal bodies and dorsal neurosecretory cells of the cerebral ganglia of Lymnaea stagnalis. Arch. Néerl. Zool. 16, 1-103.

Joosse, J. (1986). Neuropeptides: peripheral and central messengers of the brain. Prog. Clin. Biol. Res. 205, 13-32.

Joosse, J. (1987). Evolutionary aspects of neuropeptides. Prog. Brain Res. 72, 35-45.

Joosse, J., De Vlieger, T. A., and Roubos, E. W. (1982). Nervous systems of lower animals as models, with particular reference to peptidergic neurons in gastropods. Prog. Brain Res. 55, 379-404.

Kandel, E. R., Kriegstein, A., and Schacher, S. (1980). Development of the central nervous system of Aplysia in terms of the differentiation of its specific identifiable cells. Neuroscience 5, 2033-2063.

Kask, A., Harro, J., von Horsten, S., Redrobe, J. P., Dumont, Y., and Quirion, R.(2002). The neurocircuitry and receptor subtypes mediating anxiolytic-like effects of neuropeptide. Y. Neurosci. Biobehav. Rev. 26, 259-283.

Kask, A., Schioth, H. B., Mutulis, F., Wikberg, J. E., and Rago, L. (2000). Anorexigenic cocaine- and amphetamine-regulated transcript peptide intensifies fear reactions in rats. Brain Res. 857, 283-285.

Keller, L. (2004). Evolution: informational constraints on adaptation. Curr. Biol. 14, R757-R758.

Kidane, A. H., Cruijsen, P. M., OrtizBazan, M. A., Vaudry, H., Leprince, J., Kuijpers-Kwant, F. J., Roubos, E. W., and Jenks, B. G. (2007a). Actions of PACAP and VIP on melanotrope cells of Xenopus laevis. Peptides 28, 1790-1796.
Kidane, A.H., Van Dooren, S. H., Roubos, E. W., and Jenks, B. G. (2007b). Expression and physiological regulation of BDNF receptors in the neuroendocrine melanotrope cell of Xenopus laevis. Gen. Comp. Endocrinol. 153, 176-181.

Kidane,A.H., Heinrich, G., Dirks, R.P., DE Ruyck, B. A., Lubsen, N.H., Roubos, E. W., and Jenks, B. G. (2009). Differential neuroendocrine expression of multiple brain-derived neurotrophic factor transcripts. Endocrinology 150, 1361-1368.

Kidane,A.H., Roubos, E. W., and Jenks, B. G. (2008). Pituitary adenylate cyclaseactivating polypeptide regulates brainderived neurotrophic factor exon IV expression through the VPAC1 receptor in the amphibian melanotrope cell. Endocrinology 149, 4177-4182.

Kikuyama, S., Inaco, H., Jenks, B. G., and Kawamura, K. (1993). Development of the ectopically transplanted primordium of epithelial hypophysis (anterior neural ridge) in Bufo japonicus embryos. J. Exp. Zool. 266, 216-220.

Kits, K. S. (1980). States of excitability in ovulation hormone producing neuroendocrine cells of Lymnaea stagnalis (Gastropoda) and their relation to the egg-laying cycle. J. Neurobiol. 11, 397-410.

Koene, J. M., and Ter Maat, A. (2007). Coolidge effect in pond snails: male motivation in a simultaneous hermaphrodite. BMC Evol. Biol. 7, 212.

Kolk, S. M., Berghs, C. A., Vaudry, H., Verhage, M., and Roubos, E. W. (2001). Physiological control of Xunc18 expression in neuroendocrine melanotrope cells of Xenopus laevis. Endocrinology 142, 1950-1957.

Kolk, S. M., Nordquist, R., Tuinhof, R., Gagliardini, L., Thompson, B., Cools, A. R., and Roubos, E. W. (2000). Localization and physiological regulation of the exocytosis protein SNAP-25 in the brain and pituitary gland of Xenopus laevis. J. Neuroendocrinol. 12, 694-706.

Koopman, W. J., Hink, M. A., Visser, A. J., Roubos, E. W., and Jenks, B. G. (1999). Evidence that Ca2+-waves in Xenopus melanotropes depend on calcium-induced calcium release: a fluorescence correlation microscopy and linescanning study. Cell Calcium 26, 59-67.

Koopman,W.J., Scheenen,W.J., Errington, R. J., Willems, P. H., Bindels, R. J., Roubos, E. W., and Jenks, B. G. (2001). Membrane-initiated Ca2+ signals are reshaped during propagation to subcellular regions. Biophys. J. 81, 57-65.

Kornstein, S. G. (1997). Gender differences in depression: implications for treatment. J. Clin. Psychiatry 58(Suppl. 15), 12-18.
Korosi, A., Kozicz, T., Richter, J., Veening, J. G., Olivier, B., and Roubos, E. W. (2007). Corticotropin-releasing factor, urocortin 1 , and their receptors in the mouse spinal cord. J. Comp. Neurol. 502, 973-989.

Korosi, A., Schotanus, S., Olivier, B., Roubos, E. W., and Kozicz, T. (2005). Chronic ether stress-induced response of urocortin 1 neurons in the EdingerWestphal nucleus in the mouse. Brain Res. 1046, 172-179.

Korosi, A., Veening, J. G., Kozicz, T., Henckens, M., Dederen, J., Groenink, L., Van Der Gugten, J., Olivier, B., and Roubos, E. W. (2006). Distribution and expression of CRF receptor 1 and 2 mRNAs in the CRF over-expressing mouse brain. Brain Res. 1072, 46-54.

Koylu, E. O., Balkan, B., Kuhar, M. J., and Pogun, S. (2006). Cocaine and amphetamine regulated transcript (CART) and the stress response. Peptides 27, 1956-1969.

Kozicz, T. (2003). Neurons colocalizing urocortin and cocaine and amphetamine-regulated transcript immunoreactivities are induced by acute lipopolysaccharide stress in the Edinger-Westphal nucleus in the rat. Neuroscience 116, 315-320.

Kozicz, T. (2007a). CRF and CRF-related peptides in stress adaptation: from invertebrates to man. Gen. Comp. Endocrinol. 153, 198-199.

Kozicz, T. (2007b). On the role of urocortin 1 in the non-preganglionic Edinger-Westphal nucleus in stress adaptation. Gen. Comp. Endocrinol. 153, 235-240.

Kozicz, T. (2009). "Neurobiology of corticotrophin-releasing factor system components in stress; from adaptation to maladaptation," in Neuropeptides and Peptide Analogs, eds M. Kovács and L. Merchenthaler (Kerala, India: Research Signpost), 59-90.

Kozicz, T., Bordewin, L. A., Czeh, B., Fuchs, E., and Roubos, E. W. (2008a). Chronic psychosocial stress affects corticotropin-releasing factor in the paraventricular nucleus and central extended amygdala as well as urocortin 1 in the non-preganglionic Edinger-Westphal nucleus of the tree shrew. Psychoneuroendocrinology 33, 741-754.

Kozicz, T., Tilburg-Ouwens, D., Faludi, G., Palkovits, M., and Roubos, E. (2008b). Gender-related urocortin 1 and brainderived neurotrophic factor expression in the adult human midbrain of suicide victims with major depression. Neuroscience 152, 1015-1023.

Kozicz, T., Korosi,A., Korsman, C., TilburgOuwens, D., Groenink, L., Veening, J., Van Der Gugten, J., Roubos, E., and Olivier, B. (2004). Urocortin expression in the Edinger-Westphal nucleus is down-regulated in transgenic mice over-expressing neuronal corticotropin-releasing factor. Neuroscience 123, 589-594.

Kramer, B. M., Cruijsen, P. M., Ouwens, D. T., Coolen, M. W., Martens, G. J., Roubos, E. W., and Jenks, B. G. (2002a). Evidence that brain-derived neurotrophic factor acts as an autocrine factor on pituitary melanotrope cells of Xenopus laevis. Endocrinology 143, 1337-1345.

Kramer, B. M., Song, J. Y., Westphal, N. J., Jenks, B. G., and Roubos, E. W. (2002b). Regulation of neurons in the suprachiasmatic nucleus of Xenopus laevis. Comp. Biochem. Physiol. B, Biochem. Mol. Biol. 132, 269-274.

Kramer, B. M., Kolk, S. M., Berghs, C. A., Tuinhof, R., Ubink, R., Jenks, B. G., and Roubos, E.W. (2001a). Dynamics and plasticity of peptidergic control centres in the retino-brain-pituitary system of Xenopus laevis. Microsc. Res. Tech. 54, 188-199.

Kramer, B. M., Welting, J., Berghs, C. A., Jenks, B. G., and Roubos, E.W. (2001b). Functional organization of the suprachiasmatic nucleus of Xenopus laevis in relation to background adaptation. J. Comp. Neurol. 432, 346-355.

Kudielka, B. M., and Kirschbaum, C. (2005). Sex differences in HPA axis responses to stress: a review. Biol. Psychol. 69, 113-132.

Kuribara, M., Eijsink, V. D., Roubos, E. W., Jenks, B. G., and Scheenen, W. J. J. M. (2010a). BDNF stimulates $\mathrm{Ca}^{2+}$ oscillation frequency in melanotrope cells of Xenopus laevis: contribution of IP3-receptor-mediated release of intracellular $\mathrm{Ca}^{2+}$ to gene expression. Gen. Comp. Endocrinol. 169, 123-129.

Kuribara, M., Hess, M. W., Cazorla, M., Roubos, E. W., Scheenen, W .J. J. M., and Jenks, B. G. (2010b). Brain-derived neurotrophic factor stimulates growth of pituitary melanotrope cells in an autocrine way. Gen. Comp. Endocrinol. [Epub ahead of print].

Lanaud, P., Popovici, T., Normand, E., Lemoine, C., Bloch, B., and Roques, B. P. (1989). Distribution of CCK mRNA in particular regions (hippocampus, periaqueductal grey and thalamus) of the rat by in situ hybridization. Neurosci. Lett. 104, 38-42.

Leenders, H. J., De Koning, H. P., Ponten, S. P., Jenks, B. G., and Roubos, E. W (1993). Differential effects of coexisting dopamine, GABA and NPY on alpha-MSH secretion from melanotrope cells of Xenopus laevis. Life Sci. 52, 1969-1975.

Lever, J. (1957). Some remarks on neurosecretory phenomena in Ferrissia sp. (Gastropoda, Pulmonata). Proc. 
Kon. Ned. Akad. Wet. Ser. C 60, 510-522.

Lever, J., Kok, M., Meuleman, E. A., and Joosse, J. (1961). On the location of Gomori-positive neurosecretory cells in the central ganglia of Lymnaea stagnalis. Proc. Kon. Ned. Akad. Wet. Ser. C 64, 640-647.

Lewis, K., Li, C., Perrin, M. H., Blount, A., Kunitake, K., Donaldson, C., Vaughan, J., Reyes, T. M., Gulyas, J., Fischer, W., Bilezikjian, L., Rivier, J., Sawchenko, P. E., and Vale, W. W. (2001). Identification of urocortin Iii, an additional member of the corticotropin-releasing factor (CRF) family with high affinity for the CRF2 receptor. Proc. Natl. Acad. Sci. U.S.A. 98, 7570-7575.

Li, K. W., Geraerts, W. P., and Joosse, J. (1992). Purification and chemical characterization of caudodorsal cell hormone-II from the egg-laying controlling caudodorsal cells of Lymnaea stagnalis. Peptides 13, 215-220.

Li, K. W., Jimenez, C. R., Van Veelen, P. A., and Geraerts, W. P. (1994). Processing and targeting of a molluscan egg-laying peptide prohormone as revealed by mass spectrometric peptide fingerprinting and peptide sequencing. Endocrinology 134, 1812-1819.

Lieste, J. R., Koopman, W. J., Reynen, V. C., Scheenen, W. J., Jenks, B. G., and Roubos, E.W.(1998a).Action currents generate stepwise intracellular $\mathrm{Ca} 2+$ patterns in a neuroendocrine cell. $J$. Biol. Chem. 273, 25686-25694.

Lieste, J. R., Scheenen, W. J., Jenks, B. G., and Roubos, E. W. (1998b). Single cell secretion measurements by amperometry in Xenopus melanotropes. Ann. N. Y. Acad. Sci. 839, 546-548.

Linden, A. M., Greene, S. J., Bergeron, M., and Schoepp, D. D. (2004). Anxiolytic activity of the MGLU2/3 receptor agonistLY354740 on the elevated plus maze is associated with the suppression of stress-induced c-Fos in the hippocampus and increases in c-Fos induction in several other stress-sensitive brain regions. Neuropsychopharmacology29, 502-513.

Loh, Y.P., and Jenks, B. G. (1981). Evidence for two different turnover pools of adrenocorticotropin, alpha-melanocyte-stimulating hormone, and endorphin-related peptides released by the frog pituitary neurointermediate lobe. Endocrinology 109, 54-61.

Maciewicz, R., Phipps, B. S., Foote, W. E., Aronin, N., and Difiglia, M. (1983). The distribution of substance P-containing neurons in the cat Edinger-Westphal nucleus: relationship to efferent projection systems. Brain Res. 270, 217-230.

Maciewicz, R., Phipps, B.S., Grenier, J., and Poletti, C.E. (1984).Edinger-Westphal nucleus: cholecystokinin immunocytochemistry and projections to spinal cord and trigeminal nucleus in the cat. Brain Res. 299, 139-145.

Makara, G. B., Stark, E., and Mihaly, K. (1969). Corticotrophin release induced by injection of formalin in rats with hemisection of the spinal cord. Acta Physiol. Acad. Sci. Hung. 35, 331-333.

Martens, G. J. (1986). Expression of two proopiomelanocortin genes in the pituitary gland of Xenopus laevis: complete structures of the two preprohormones. Nucleic Acids Res. 14, 3791-3798.

Martens, G. J., Biermans, P. P., Jenks, B. G., and Van Overbeeke, A. P. (1982). Biosynthesis of two structurally different pro-opiomelanocortins in the pars intermedia of the amphibian pituitary gland. Eur. J. Biochem. 126, 17-22.

Martens, G. J., Groenen, P. M., Groneveld, D., and Van Riel, M. C. (1993). Expression of the Xenopus D2 dopamine receptor. Tissue-specific regulation and two transcriptionally active genes but no evidence for alternative splicing. Eur. J. Biochem. 213, 1349-1354.

Martens, G. J., Jenks, B. G., and Van Overbeeke, A. P. (1981a). Microsuperfusion of neurointermediate lobes of Xenopus laevis: concomitant and coordinately controlled release of newly synthesized peptides. Comp. Biochem. Physiol. 69C, 75-82.

Martens, G. J., Jenks, B. G., and Van Overbeeke, A. P. (1981b). N alphaacetylation is linked to alpha-MSH release from pars intermedia of the amphibian pituitary gland. Nature 294, 558-560.

May, P. J., Reiner, A. J., and Ryabinin, A. E. (2008). Comparison of the distributions of urocortin-containing and cholinergic neurons in the perioculomotor midbrain of the cat and macaque. J. Comp. Neurol. 507, 1300-1316.

Merila, J. (2009). Evolution. Genetic constraints on adaptation? Science 325 , 1212-1213.

Millan, M. J. (1999). The induction of pain: an integrative review. Prog. Neurobiol. 57, 1-164.

Mizrahi, A., Lu, J., Irving, R., Feng, G., and Katz, L. C. (2006) In vivo imaging of juxtaglomerular neuron turnover in the mouse olfactory bulb. Proc. Natl. Acad. Sci. U. S. A. 103, 1912-1917.

Morin, L. P., and Meyer-Bernstein, E. L. (1999). The ascending serotonergic system in the hamster: comparison with projections of the dorsal and median raphe nuclei. Neuroscience 91, 81-105.

Okere, B., Xu, L., Roubos, E. W., Sonetti, D., and Kozicz, T. (2010). Restraint stress alters the secretory activity of neurons co-expressing urocortin-1, cocaine- and amphetamine-regulated transcript peptide and nesfatin- 1 in the mouse Edinger-Westphal nucleus. Brain Res. 1317, 92-99.

Otake, K. (2005). Cholecystokinin and substance $\mathrm{P}$ immunoreactive projections to the paraventricular thalamic nucleus in the rat. Neurosci. Res. 51, 383-394.

Pan, W., and Kastin, A. J. (2008). Urocortin and the brain. Prog. Neurobiol. 84, 148-156.

Phipps, B. S., Maciewicz, R., Sandrew, B. B., Poletti, C. E., and Foote, W. E. (1983). Edinger-Westphal neurons that project to spinal cord contain substance P. Neurosci. Lett. 36, 125-131.

Piazza, P. V., and Le Moal, M. (1998) The role of stress in drug self-administration. Trends Pharmacol. Sci. 19, 67-74.

Pinsker, H. M., and Dudek, F. E. (1977). Bag cell control of egg laying in freely behaving Aplysia. Science 197, 490-493.

Plesch, B., De Jong-Brink, M., and Boer, H. H. (1971). Histological and histochemical observations on the reproductive tract of the hermaphrodite pond snail Lymnaea stagnalis. Neth. J. Zool. 21, 180-201.

Ravigne, V., Dieckmann, U., and Olivieri, I. (2009). Live where you thrive: joint evolution of habitat choice and local adaptation facilitates specialization and promotes diversity. Am. Nat. 174, E141-E169.

Reyes, T. M., Lewis, K., Perrin, M. H. Kunitake, K. S., Vaughan, J., Arias, C. A., Hogenesch, J. B., Gulyas, J., Rivier, J., Vale, W. W., and Sawchenko, P. E. (2001). Urocortin II: a member of the corticotropin-releasing factor (CRF) neuropeptide family that is selectively bound by type 2 CRF receptors. Proc Natl. Acad. Sci. U.S.A. 98, 2843-2848.

Rothman, B. S., Mayeri, E., Brown, R. O. Yuan, P. M., and Shively, J. E. (1983). Primary structure and neuronal effects of alpha-bag cell peptide, a second candidate neurotransmitter encoded by a single gene in bag cell neurons of Aplysia. Proc. Natl. Acad. Sci. U.S.A. 80, 5753-5757.

Roubos, E. W. (1973). Regulation of neurosecretory activity in the freshwater pulmonate Lymnaea stagnalis (L.). A quantitative electron microscopical study. Z. Zellforsch. Mikrosk. Anat. 146, 177-205.

Roubos, E. W. (1975). Regulation of neurosecretory activity in the freshwater pulmonate Lymnaea stagnalis (L.) with particular reference to the role of the eyes: a quantitative electron microscopical study. Cell Tissue Res. 160, 291-314.
Roubos, E. W. (1976). Neuronal and non-neuronal control of the neurosecretory caudo-dorsal cells of the freshwater snail Lymnaea stagnalis (L.). Cell Tissue Res. 168, 11-31.

Roubos, E. W. (1984). Cytobiology of the ovulation-neurohormone producing neuroendocrine caudo-dorsal cells of Lymnaea stagnalis. Int. Rev. Cytol. 89, 295-346.

Roubos, E. W. (1997). Background adaptation by Xenopus laevis: a model for studying neuronal information processing in the pituitary pars intermedia. Comp. Biochem. Physiol. A Physiol. 118, 533-550.

Roubos,E.W., andBuma,P.(1982).Cellular mechanisms of neurohormone release in the snail Lymnaea stagnalis. Prog. Brain Res. 55, 185-195.

Roubos, E. W., Kuribara, M., KuipersKwant, F.J., Coenen, T.A., Meijer, K. H., Cruijsen, P.M., and Denver, R. J. (2009). Dynamics of glucocorticoid and mineralocorticoid receptors in the Xenopus laevispituitary pars intermedia. Ann. N. Y. Acad. Sci. 1163, 292-295.

Roubos, E. W., Lazar, G., Calle, M., Barendregt, H. P., Gaszner, B., and Kozicz, T. (2008). Brain distribution and evidence for both central and neurohormonal actions of cocaine- and amphetamine-regulated transcript peptide in Xenopus laevis. J. Comp. Neurol. 507, 1622-1638.

Roubos, E. W., Martens, G. J., and Jenks, B. G. (1993). Control of melanotrope cell activity in Xenopus laevis. Ann. N. Y. Acad. Sci. 680, 130-134.

Roubos, E. W., Scheenen, W. J., Cruijsen, P. M., Cornelisse, L. N., Leenders, H. J., and Jenks, B. G. (2002). New aspects of signal transduction in the Xenopus laevis melanotrope cell. Gen. Comp. Endocrinol. 126, 255-260.

Roubos, E. W., Scheenen, W. J., and Jenks, B. G. (2005). Neuronal, neurohormonal, and autocrine control of Xenopus melanotrope cell activity. Ann. N. Y. Acad. Sci. 1040, 172-183.

Roubos, E. W., and Van De Ven, A. M. H. (1987). Morphology of neurosecretory cells in Basommatophoran snails homologous with egg-laying and growth-hormone producing cells of Lymnaea stagnalis. Gen. Comp. Endocrinol. 67, 7-23.

Roubos, E. W., and Van Der Wal-Divendal, R. M. (1980). Ultrastructural analysis of peptide-hormone release by exocytosis. Cell Tissue Res. 207, 267-275.

Roubos, E. W., and Van Heumen, W. R. (1994). Peptide processing and release by the neuroendocrine caudodorsal cells of Lymnaea stagnalis during an egg-laying cycle. Brain Res. 644, 83-89.

Roubos, E. W., Van Leeuwen, J. P., and Maijers, A. (1985). Ultrastructure of 
gap junctions in the central nervous system of Lymnaea stagnalis with particular reference to electrotonic coupling between the neuroendocrine caudodorsal cells. Neuroscience 14, 711-721.

Roubos, E. W., Van Wijk, D. C. W. A., and Kozicz, L. T., Scheenen, W. J. J. M., and Jenks, B. G. (2010). Plasticity in melanotrope cell regulations in Xenopus laevis. Eur. J. Neurosci. (in press).

Rouwette, T. P., Kozicz, T., Olde Loohuis, N. F., Gaszner, B., Vreugdenhil, E., Scheffer, G. J., Roubos, E. W., Vissers, K. C., and Scheenen, W. J. (2010). Acute pain Increases phosphorylation of DCLK-long in the Edinger-Westphal nucleus but not in the hypothalamic paraventricular nucleus of the rat. $J$. Pain 11, 930-940.

Ryabinin, A. E., Tsivkovskaia, N. O., and Ryabinin, S. A. (2005). Urocortin 1-containing neurons in the human Edinger-Westphal nucleus. Neuroscience 134, 1317-1323.

Ryabinin, A. E., and Weitemier, A. Z. (2006). The urocortin 1 neurocircuit: ethanol-sensitivity and potential involvement in alcohol consumption. Brain Res. Rev. 52, 368-380.

Sánchez-Lasheras, C., Könner, A. C., and Brüning, J. C. (2010). Integrative neurobiology of energy homeostasisneurocircuits, signals and mediators. Front. Neuroendocrinol. 31:4-15. doi: 10.1016/j.yfrne.2009.08.002.

Saper, C. B., and Loewy, A. D. (1980). Efferent connections of the parabrachial nucleus in the rat. Brain Res. 197, 291-317.

Sarnat, H. B. (1983). The discovery, proof and reproof of neurosecretion (Speidel, 1917; Scharrer and Scharrer, 1934). Can. J. Neurol. Sci. 10, 208-212.

Scharrer, E. (1952). Pituitary-diencephalic system of Scyllium stellare. Z. Zellforsch. Mikrosk. Anat. 37, 196-204.

Scharrer, E. (1954). Neurosecretion and anterior pituitary in the dog. Experientia 10, 264-266.

Scharrer, E., and Scharrer, B. (1953). Symposium on neurosecretion at Naples, Italy. Science 118, 579-580.

Scheenen, W. J., Jansen, E. J., Roubos, E. W., and Martens, G. J. (2009). Using transgenic animal models in neuroendocrine research: lessons from Xenopus laevis. Ann. N. Y. Acad. Sci. 1163, 296-307.

Scheenen, W. J., Jenks, B. G., Roubos, E. W., and Willems, P. H. (1994). Spontaneous calcium oscillations in Xenopus laevis melanotrope cells are mediated by omega-conotoxin sensitive calcium channels. Cell Calcium $15,36-44$.

Scheenen, W. J., Jenks, B. G., Van Dinter, R. J., and Roubos, E. W. (1996). Spatial and temporal aspects of $\mathrm{Ca}^{2+}$ oscillations in Xenopus laevis melanotrope cells. Cell Calcium 19, 219-227.

Scheenen, W. J., Jenks, B. G., Willems, P. H., and Roubos, E. W. (1993). Spontaneous calcium oscillations in melanotrope cells of Xenopus laevis. Ann. N. Y. Acad. Sci. 680, 603-605.

Scheenen, W. J., Yntema, H. G., Willems, P. H., Roubos, E. W., Lieste, J. R., and Jenks, B. G. (1995). Neuropeptide Y inhibits Ca2+oscillations, cyclic AMP, and secretion in melanotrope cells of Xenopus laevis via a Y1 receptor. Peptides 16, 889-895.

Scheller, R. H., Jackson, J. F., Mcallister, L. B., Rothman, B. S., Mayeri, E., and Axel, R. (1983). A single gene encodes multiple neuropeptides mediating a stereotyped behavior. Cell 32, 7-22.

Schmidt, E. D., and Roubos, E. W. (1987). Morphological basis for nonsynaptic communication within the central nervous system by exocytotic release of secretory material from the egglaying stimulating neuroendocrine caudodorsal cells of Lymnaea stagnalis. Neuroscience 20, 247-257.

Schmidt, E. D., and Roubos, E. W. (1988). Structural aspects, potassium stimulation and calcium dependence of nonsynaptic neuropeptide release by the egg laying controlling caudodorsal cells of Lymnaea stagnalis. Neuroscience 26, 327-335.

Schmidt, E. D., and Roubos, E. W. (1989). Quantitative immunoelectron microscopy and tannic acid study of dynamics of neurohaemal and non-synaptic peptide release by the caudodorsal cells of Lymnaea stagnalis. Brain Res. 489, 325-337.

Sigvardt, K. A., Rothman, B. S., Brown, R. O., and Mayeri, E. (1986). The bag cells of Aplysia as a multitransmitter system: identification of alpha bag cell peptide as a second neurotransmitter. J. Neurosci. 6, 803-813.

Skelton, K.H., Owens, M. J., and Nemeroff, C. B. (2000). The neurobiology of urocortin. Regul. Pept. 93, 85-92.

Sminia, T. (1972). Structure and function of blood and connective tissue cells of the fresh water pulmonate Lymnaea stagnalis studied by electron microscopy and enzyme histochemistry. Z. Zellforsch. Mikrosk. Anat. 130, 497-526.

Smith, M. A., Makino, S., Kim, S. Y., and Kvetnansky, R. (1995). Stress increases brain-derived neurotropic factor messenger ribonucleic acid in the hypothalamus and pituitary. Endocrinology 136, 3743-3750.

Stay, B. (2000). A review of the role of neurosecretion in the control of juvenile hormone synthesis: a tribute to Berta Scharrer. Insect Biochem. Mol. Biol. 30, 653-662.
Takeuchi, Y., Kimura, H., and Sano, Y. (1982). Immunohistochemical demonstration of the distribution of serotonin neurons in the brainstem of the rat and cat. Cell Tissue Res. 224 247-267.

Tanaka, H., Yoshida, T., Miyamoto, N., Motoike, T., Kurosu, H., Shibata, K., Yamanaka, A., Williams, S. C., Richardson, J.A., Tsujino, N., Garry, M G., Lerner, M. R., King, D. S., O’Dowd, B. F., Sakurai, T., and Yanagisawa, M. (2003). Characterization of a family of endogenous neuropeptide ligands for the $\mathrm{G}$ protein-coupled receptors GPR7 and GPR8. Proc. Natl. Acad. Sci. U.S.A 100, 6251-6256.

Taylor, B. K., Akana, S. F., Peterson, M. A., Dallman, M. F., and Basbaum, A. I. (1998). Pituitary-adrenocortical responses to persistent noxious stimul in the awake rat: endogenous corticosterone does not reduce nociception in the formalin test. Endocrinology 139, 2407-2413.

Ter Maat, A. (1992). Egg laying in the hermaphrodite pond snail Lymnaea stagnalis. Prog. Brain Res. 92, 345-360.

Ter Maat, A., Geraerts, W. P., Jansen, R. F., and Bos, N. P. (1988). Chemically mediated positive feedback generates long-lasting afterdischarge in a molluscan neuroendocrine system. Brain Res. 438, 77-82.

Ter Maat, A., Lodder, J. C., and Wilbrink, M. (1983a). Induction of egg laying in the pond snail Lymnaea stagnalis by environmental stimulation of the release of ovulation hormone from the caudodorsal cells. Int. J. Invert. Reprod. 6, 239-247.

Ter Maat, A., Roubos, E. W., Lodder, J. C. and Buma, P. (1983b). Integration of biphasic synaptic input by electrotonically coupled neuroendocrine caudodorsal cells in the pond snail. $J$. Neurophysiol. 49, 1392-1409.

Terlou, M., Gijben, C. A., and Van Oordt, P. G. (1975). Effect of hypothalamic lesions on colour change in tadpoles of Xenopus laevis. J. Endocrinol. 64 $61 \mathrm{P}$.

Terlou, M., and Van Straaten, H.W. (1973). The development of a hypothalamic monoaminergic system for the regulation of the pars intermedia activity in Xenopus laevis. Z. Zellforsch. Mikrosk Anat. 143, 229-238.

Theunis, W., Van Minnen, J., and De Loof,A. (1990). Immunocytochemical localization in the central nervous system of four different insect species of molecules immunoreactive against peptides present in the caudodorsal cells of Lymnaea stagnalis. Gen. Comp. Endocrinol. 79, 415-422.

Thornton, V. F., Weatherhead, B., and Whur, P. (1970). The effects of change of background colour on the rate of
$3 \mathrm{H}$-leucine incorporation and total melanocyte-stimulating hormone content of the pars intermedia of Xenopus laevis. J. Endocrinol. 48, xxv-xxvi.

Thorsell, A., Carlsson, K., Ekman, R., and Heilig, M. (1999). Behavioral and endocrine adaptation, and upregulation of NPY expression in rat amygdala following repeated restraint stress. Neuroreport 10, 3003-3007.

Tonosaki, Y., Cruijsen, P. M., Nishiyama, K., Yaginuma, H., and Roubos, E. W. (2004). Low temperature stimulates alpha-melanophore-stimulating hormone secretion and inhibits background adaptation in Xenopus laevis. J. Neuroendocrinol. 16, 894-905.

Tuinhof, R., Artero, C., Fasolo, A., Franzoni, M. F., Ten Donkelaar, H. J., Wismans, P. G., and Roubos, E. W. (1994). Involvement of retinohypothalamic input, suprachiasmatic nucleus, magnocellular nucleus and locus coeruleus in control of melanotrope cells of Xenopus laevis: a retrograde and anterograde tracing study. Neuroscience 61, 411-420.

Tuinhof, R., De Rijk, E. P., Wismans, R. G., Smeets, W. J., and Roubos, E. W. (1993a). The role of hypothalamic nuclei in the dopaminergic control of background adaptation in Xenopus laevis. Ann. N. Y. Acad. Sci. 680, 486-488.

Tuinhof, R., Laurent, F. Y., Ebbers, R. G., Smeets, W. J., Van Riel, M. C., and Roubos, E. W. (1993b). Immunocytochemistry and in situ hybridization of neuropeptide $\mathrm{Y}$ in the hypothalamus of Xenopus laevis in relation to background adaptation. Neuroscience 55, 667-675.

Ubink, R., Buzzi, M., Cruijsen, P. M., Tuinhof, R., Verhofstad, A. A., Jenks, B. G., and Roubos, E. W. (1999). Serotonergic innervation of the pituitary pars intermedia of Xenopus laevis. J. Neuroendocrinol. 11, 211-219.

Ubink, R., Jenks, B. G., and Roubos, E. W. (1997). Physiologically induced Fos expression in the hypothalamohypophyseal system of Xenopus laevis. Neuroendocrinology 65, 413-422.

Ubink, R., Tuinhof, R., and Roubos, E. W. (1998). Identification of suprachiasmatic melanotrope-inhibiting neurons in Xenopus laevis: a confocal laser-scanning microscopy study. $J$. Comp. Neurol. 397, 60-68.

Valentino, R. J., and Commons, K. G. (2005). Peptides that fine-tune the serotonin system. Neuropeptides 39 , $1-8$.

Van de Veerdonk, F. C. (1969). A contribution to the analysis of the mechanism of MSH-induced dispersion in the melanophores of Xenopus laevis. Gen. Comp. Endocrinol. 12, 658-660. 
Van den Hurk, M. J., Cruijsen, P. M., Schoeber, J. P., Scheenen, W. J., Roubos, E. W., and Jenks, B. G. (2008). Intracellular signal transduction by the extracellular calcium-sensing receptor of Xenopus melanotrope cells. Gen. Comp. Endocrinol. 157, 156-164.

Van den Hurk, M. J., Jenks, B. G., Roubos, E. W., and Scheenen, W. J. (2005a). The extracellular calcium-sensing receptor increases the number of calcium steps and action currents in pituitary melanotrope cells. Neurosci. Lett. 377, 125-129.

Van den Hurk, M. J., Scheenen, W. J., Roubos, E. W., and Jenks, B. G. (2005b). Calcium influx through voltage-operated calcium channels is required for proopiomelanocortin protein expression in Xenopus melanotropes. Ann. N. Y. Acad. Sci. 1040, 494-497.

Van den Hurk, M. J., Ouwens, D. T., Scheenen, W. J., Limburg, V., Gellekink, H., Bai, M., Roubos, E. W., and Jenks, B. G. (2003). Expression and characterization of the extracellular $\mathrm{Ca} 2+$-sensing receptor in melanotrope cells of Xenopus laevis. Endocrinology 144, 2524-2533.

Van Heumen, W. R., Broers-Vendrig, C. M., and Roubos, E. W. (1992). Light and electron microscopic immunocytochemical demonstration of synthesis, storage, and release sites of the neuropeptide calfluxin in Lymnaea stagnalis. Gen. Comp. Endocrinol. 87, 361-368.

Van Heumen, W. R., and Roubos, E. W. (1991). Immuno-electron microscopy of sorting and release of neuropeptides in Lymnaea stagnalis. Cell Tissue Res. 264, 185-195.

Van Oordt, P. G. W. J., Goos, H. J. T., Peute, J., and Terlou, M. (1972). Hypothalamo-hypophysial relations in amphibian larvae. Gen. Comp. Endocrinol. 3(Suppl. 1), 41-50.

Van Pett, K., Viau, V., Bittencourt, J. C., Chan, R. K., Li, H.Y., Arias, C., Prins, G. S., Perrin, M., Vale, W., and Sawchenko, P. E. (2000). Distribution of mRNAs encoding CRF receptors in brain and pituitary of rat and mouse. J. Comp. Neurol. 428, 191-212.

Van Strien, F. J., De Rijk, E. P., Heymen, P. S., Hafmans, T. G., and Roubos, E. W. (1991). Demonstration of dopamine in electron-dense synaptic vesicles in the pars intermedia of Xenopus laevis, by freeze substitution and postembedding immunogold electron microscopy. Histochemistry 96, 505-510.

Van Strien, F. J., Devreese, B., Van Beeumen, J., Roubos, E. W., and Jenks, B. G. (1995a). Biosynthesis and processing of the $\mathrm{N}$-terminal part of proopiomelanocortin in Xenopus laevis: characterization of gammaMSH peptides. J. Neuroendocrinol. 7, 807-815.
Van Strien, F. J., Galas, L., Jenks, B. G., and Roubos, E. W. (1995b). Differential acetylation of pro-opiomelanocortin-derived peptides in the pituitary gland of Xenopus laevis in relation to background adaptation. J. Endocrinol. 146, 159-167.

Van Strien, F. J., Jenks, B. G., Heerma, W., Versluis, C., Kawauchi, H., and Roubos, E. W. (1993). Alpha,Nacetyl beta-endorphin [1-8] is the terminal product of processing of endorphins in the melanotrope cells of Xenopus laevis, as demonstrated by FAB tandem mass spectrometry. Biochem. Biophys. Res. Commun. 191, 262-268.

Van Strien, F. J., Jenks, B. G., Vaudry, H., and Roubos, E. W. (1998). Cholinergic regulation of the pituitary: autoexcitatory control by acetylcholine of melanotrope cell activity in Xenopus laevis. Ann. N. Y. Acad. Sci. 839, 66-73.

Van Strien, F. J., Roubos, E. W., Vaudry, H., and Jenks, B. G. (1996). Acetylcholine autoexcites the release of proopiomelanocortin-derived peptides from melanotrope cells of Xenopus laevis via an $\mathrm{M} 1$ muscarinic receptor. Endocrinology 137, 4298-4307.

Van Wijk, D.C., Meijer, K.H., and Roubos, E. W. (2010). Ultrastructural and neurochemical architecture of the pituitary neural lobe of Xenopus laevis. Gen. Comp. Endocrinol. 68, 293-301.

Van Wijk, D. C., and Roubos, E. W. (2009). Neurochemistry and plasticity of the median eminence and neural pituitary lobe in relation to background adaptation of Xenopus laevis. Ann. N. Y. Acad. Sci. 1163, 524-527.

Van Wijk, D. C., Xu, L., Spiegelberg, L., Struik, R. F., Meijer, K. H., Gaszner, B., Kozicz, T., and Roubos, E. W. (2009). Ultrastructural and immunocytochemical characterization of the rat non-preganglionic Edinger-Westphal nucleus. Gen. Comp. Endocrinol. 164, 32-39.

Vaudry, H., Jenks, B. G., and Van Overbeeke, A. P. (1983). The frog pars intermedia contains only the non-acetylated form of alpha-MSH: acetylation to generate alpha-MSH occurs during the release process. Life Sci. 33(Suppl. 1), 97-100.

Vaudry, H., Jenks, B. G., and Van Overbeeke, A. P. (1984). Biosynthesis, processing and release of pro-opiomelanocortin related peptides in the intermediate lobe of the pituitary gland of the frog (Rana ridibunda). Peptides 5, 905-912.

Vaudry, H., Oliver, C., Usategui, R., Trochard, M. C., Leboulenger, F., Dupont, W., and Vaillant, R. (1976). Melanotropic hormone in the green frog (Rana esculenta): biochemical and radioimmunological study. C.R. Hebd.
Seances Acad. Sci., Ser. D, Sci. Nat. 283, 1655-1658.

Vaudry, H., Roubos, E., Schoofs, L., Flik, G., and Larhammar, D. (2005). Trends in comparative endocrinology and neurobiology. Ann. N. Y. Acad. Sci. 1040, 529

Vaughan, J., Donaldson, C., Bittencourt, J., Perrin, M. H., Lewis, K., Sutton, S. Chan, R., Turnbull, A. V., Lovejoy, D., Rivier, C., Rivier, J., Sawchenko, P. E., and Vale, W. W. (1995). Urocortin, a mammalian neuropeptide related to fish urotensin I and to corticotropin-releasing factor. Nature 378 287-292.

Vazquez-Martinez, R.M.,Malagon,M.M., Van Strien, F. J., Jespersen, S., Van Der Greef, J., Roubos, E. W., and GRACIANavarro, F. (1999). Analysis by mass spectrometry of POMC-derived peptides in amphibian melanotrope subpopulations. Life Sci. 64, 923-930.

Verburg-Van Kemenade, B. M., Jenks, B. G., Danger, J. M., Vaudry, H., Pelletier, G., and Saint-Pierre, S. (1987a). An NPY-like peptide may function as MSH-release inhibiting factor in Xenopus laevis. Peptides 8, 61-67.

Verburg-Van Kemenade, B. M., Jenks, B. G., Lenssen, F. J., and Vaudry, H. (1987b). Characterization of gamma-aminobutyric acid receptors in the neurointermediate lobe of the amphibian Xenopus laevis. Endocrinology 120, 622-628.

Verburg-Van Kemenade, B. M., Jenks, B. G., Visser, T. J., Tonon, M. C., and Vaudry, H. (1987c). Assessment of TRH as a potential MSH release stimulating factor in Xenopus laevis. Peptides 8, 69-76.

Verburg-Van Kemenade, B. M., Jenks, B. G., and Driessen, A. G. (1986a). GABA and dopamine act directly on melanotropes of Xenopus to inhibit MSH secretion. Brain Res. Bull. 17, 697-704.

Verburg-Van Kemenade, B. M., Jenks, B. G., and Van Overbeeke, A. P. (1986b). Regulation of melanotropin release from the pars intermedia of the amphibian Xenopus laevis: evaluation of the involvement of serotonergic, cholinergic, or adrenergic receptor mechanisms. Gen. Comp. Endocrinol. $63,471-480$.

Verburg-Van Kemenade, B. M., Tappaz, M., Paut, L., and Jenks, B. G. (1986c). GABAergic regulation of melanocytestimulating hormone secretion from the pars intermedia of Xenopus laevis: immunocytochemical and physiological evidence. Endocrinology 118 260-267.

Verburg-Van Kemenade, B. M., Tonon, M. C., Jenks, B. G., and Vaudry, H. (1986d). Characteristics of receptors for dopamine in the pars interme- dia of the amphibian Xenopus laevis. Neuroendocrinology 44, 446-456.

Vetter, D. E., Li, C., Zhao, L., Contarino, A., Liberman, M. C., Smith, G. W., Marchuk, Y., Koob, G. F., Heinemann, S. F., Vale, W., and Lee, K. F. (2002). Urocortin-deficient mice show hearing impairment and increased anxiety-like behavior. Nat. Genet. 31, 363-369.

Viau, V., and Sawchenko, P. E. (2002). Hypophysiotropic neurons of the paraventricular nucleus respond in spatially, temporally, and phenotypically differentiated manners to acute vs. repeated restraint stress: rapid publication. J. Comp. Neurol. 445, 293-307.

Volcanes, B., and Weatherhead, B. (1976) Stereological analysis of the effects of 6-hydroxydopamine on the ultrastructure of the melanocyte-stimulating hormone cell of the pars intermedia of the pituitary of Xenopus laevis. Gen. Comp. Endocrinol. 28, 205-212.

Vreugdenhil, E., Geraerts, W. P., Jackson, J. F., and Joosse, J. (1985). The molecular basis of the neuro-endocrine control of egg-laying behaviour in Lymnaea. Peptides 6(Suppl. 3), 465-470.

Vreugdenhil,E.,Jackson,J.F., Bouwmeester, T., Smit, A. B., Van Minnen, J., Van Heerikhuizen, H., Klootwijk, J., and Joosse, J. (1988). Isolation, characterization, and evolutionary aspects of a cDNA clone encoding multiple neuropeptides involved in the stereotyped egg-laying behavior of the freshwater snail Lymnaea stagnalis. J. Neurosci. 8, 4184-4191.

Wang, L., Calle, M., and Roubos, E. W. (2005). Brain-derived neurotrophic factor in the hypothalamo-hypophyseal system of Xenopus laevis. Ann. N. Y. Acad. Sci. 1040, 512-514.

Wang, L. C., Meijer, H. K., Humbel, B. M., Jenks, B. G., and Roubos, E. W. (2004). Activity-dependent dynamics of coexisting brain-derived neurotrophic factor, pro-opiomelanocortin and alpha-melanophore-stimulating hormone in melanotrope cells of Xenopus laevis. J. Neuroendocrinol. 16, 19-25.

Watabe, T., Tanaka, K., Kumagae, M., Itoh, S., Hasegawa, M., Horiuchi, T., Miyabe, S., Ohno, H., and Shimizu, N. (1987). Diurnal rhythm of plasma immunoreactive corticotropin-releasing factor in normal subjects. Life Sci. 40, 1651-1655.

Weatherhead, B., and Whur, P. (1972). Quantification of ultrastructural changes in the ,melanocyte-stimulating hormone cell' of the pars intermedia of the pituitary of Xenopus laevis, produced by change of background colour. J. Endocrinol. 53, 303-310.

Weinert, C., Cudney, S., and Spring, A. (2008). Evolution of a conceptual 
model for adaptation to chronic illness. J. Nurs. Scholarsh. 40, 364-372.

Weitemier, A. Z., Tsivkovskaia, N. O., and Ryabinin,A.E. (2005). Urocortin 1 distribution in mouse brain is strain-dependent. Neuroscience 132, 729-740.

Wendelaar Bonga, S. E. (1970). Ultrastructure and histochemistry of neurosecretory cells and neurohaemal areas in the pond snail Lymnaea stagnalis (L.). Z. Zellforsch. Mikrosk. Anat. 108, 190-224.

Wendelaar Bonga, S.E. (1971). Formation, storage, and release of neurosecretory material studied by quantitative electron microscopy in the fresh water snail Lymnaea stagnalis (L.). Z. Zellforsch. Mikrosk. Anat. 113, 490-517.

Wendelaar Bonga, S. E., and Boer, H. H. (1969). Ultrastructure of the renopericardial system in the pond snail Lymnaea stagnalis (L.). Z. Zellforsch. Mikrosk. Anat. 94, 513-529.

Weninger, S. C., Dunn, A. J., Muglia, L. J., Dikkes, P., Miczek, K. A., Swiergiel, A. H., Berridge, C. W., and Majzoub, J. A. (1999). Stress-induced behaviors require the corticotropin-releasing hormone (CRH) receptor, but not CRH. Proc. Natl. Acad. Sci. U.S.A. 96, 8283-8288.

Weninger, S.C., Peters, L. L., and Majzoub, J. A. (2000). Urocortin expression in the Edinger-Westphal nucleus is upregulated by stress and corticotropin-releasing hormone deficiency. Endocrinology 141, 256-263.

Westphal, C. (1887). Über einen fall von chronischer progressiver Lähmung der Augenmuskeln (Ophtalmoplegia externa) nebst Beschreibung von Ganglienzellengruppen im Bereiche des Oculomotoriuskerns. Arch. Psychiatr. Nervenkr. (Berlin) 98, 846-871.

Xu, L., Bloem, B., Gaszner, B., Roubos, E. W., and Kozicz, T. (2009). Sexspecific effects of fasting on urocortin 1 , cocaine- and amphetamine-regulated transcript peptide and nesfatin-1 expression in the rat Edinger-Westphal nucleus. Neuroscience 162, 1141-1149.

Xu, L., Bloem, B., Gaszner, B., Roubos, E. W., and Kozicz, T. (2010). Stress-related changes in the activity of cocaine- and amphetamine-regulated transcript and nesfatin neurons in the midbrain nonpreganglionicEdinger-Westphal nucleus in the rat. Neuroscience 170, 478-488.

Yamada, I., Nakagawa, T., Matsushima, Y., and Shibuya, H. (2001). Highresolution turbo magnetic resonance angiography for diagnosis of Moyamoya disease. Stroke 32, 1825-1831.
Yamazoe, M., Shiosaka, S., Emson, P. C., and Tohyama, M. (1985). Distribution of neuropeptide $\mathrm{Y}$ in the lower brainstem: an immunohistochemical analysis. Brain Res. 335, 109-120.

Yu, X., Byrne, J. H., and Baxter, D. A. (2004). Modeling interactions between electrical activity and second-messenger cascades in Aplysia neuron R15. J. Neurophysiol. 91, 2297-2311.

Zhang, H., Jenks, B. G., Ciccarelli, A., Roubos, E. W., and Scheenen, W. J. (2004). Dopamine D2-receptor activation differentially inhibits $\mathrm{N}$ - and R-type Ca2+ channels in Xenopus melanotrope cells. Neuroendocrinology 80, 368-378.

Zhang, H. Y., Langeslag, M., Breukels, V., Jenks, B. G., Roubos, E. W., and Scheenen, W. J. (2008). Calcium channel kinetics of melanotrope cells in Xenopus laevis depend on environmental stimulation. Gen. Comp. Endocrinol. 156, 104-112.

Zhang, H. Y., Langeslag, M., Voncken, M., Roubos, E. W., and Scheenen, W. J. (2005). Melanotrope cells of Xenopus laevis express multiple types of highvoltage-activated $\mathrm{Ca} 2+$ channels. J. Neuroendocrinol. 17, 1-9.

Zhang, H. Y., Roubos, E. W., Jenks, B. G., and Scheenen, W. J. (2006). Receptors for neuropeptide Y, gamma-aminobu- tyric acid and dopamine differentially regulate $\mathrm{Ca} 2+$ currents in Xenopus melanotrope cells via the $G(i)$ protein beta/gamma-subunit.Gen. Comp. Endocrinol. 145, 140-147.

Conflict of Interest Statement: The authors declare that the research was conducted in the absence of any commercial or financial relationships that could be construed as a potential conflict of interest.

Received: 18 August 2010; paper pending published: 20 September 2010; accepted: 29 September 2010; published online: 20 October 2010.

Citation: Roubos EW, Jenks BG, Xu L, Kuribara M, Scheenen WJJM and Kozicz $T$ (2010) About a snail, a toad and rodents: animal models for adaptation research. Front. Endocrin. 1:4. doi: 10.3389/fendo. 2010.00004

This article was submitted to Frontiers in Neuroendocrine Science, a specialty of Frontiers in Endocrinology.

Copyright () 2010 Roubos, Jenks, Xu, Kuribara, Scheenen and Kozicz. This is an open-access article subject to an exclusive license agreement between the authors and the Frontiers Research Foundation, which permits unrestricted use, distribution, and reproduction in any medium, provided the original authors and source are credited. 